\title{
WHO IS MORE ETHICAL? CROSS CULTURAL COMPARISON OF CONSUMER ETHICS BETWEEN RELIGIOUS AND NON-RELIGIOUS CONSUMERS
}

\author{
Denni Arli, PhD* \\ Department of Marketing \\ Griffith Business School \\ Griffith University \\ Nathan, QLD 4111, AUSTRALIA \\ Phone: +61 73735 7344; Fax: +61 737357126 \\ Email: d.arli@griffith.edu.au
}

Andre Pekerti, PhD

The University of Queensland

UQ Business School

St. Lucia, QLD 4072, AUSTRALIA

Phone: +61 7 33468143; Facsimile: +61 733468166

E-mail: a.pekerti@business.uq.edu.au 
Who is more ethical?

\title{
WHO'S MORE ETHICAL? CROSS CULTURAL COMPARISON OF CONSUMER ETHICS BETWEEN RELIGIOUS AND NON-RELIGIOUS CONSUMERS
}

\begin{abstract}
Religion is a significant part of daily life that affects consumers' decisions and behaviors.

Religious consumers are predicted to be more ethical than non-religious consumers.

Nonetheless, past research suggests mixed results. Hence, the present study has two main objectives: (1) to examine differences in moral ideologies and ethical beliefs among religious and non-religious consumers in Indonesia and Australia, and (2) to investigate the impact of moral ideologies and religiosity on consumer ethical beliefs. This is one of the first crosscultural studies to compare consumer moral ideology (specifically, idealism and relativism) and consumer ethical beliefs between religious and non-religious consumers. The results show that religious consumers tend more toward idealism than relativism and have stronger ethical beliefs regarding negative consumer ethical behaviors compared to non-religious consumers. However, for ethical beliefs regarding specific consumer behaviors, namely recycling and software piracy/buying counterfeit, the effect of religion was overshadowed by cultural differences between the two countries. This study contributes to the debate on the impact of moral ideologies and religiosity on consumer ethical beliefs. The findings may assist managers and public policymakers in their efforts to mitigate unethical consumer activities.
\end{abstract}

Keywords: Consumer Ethics, Idealism, Relativism, Religiosity, Australia, Indonesia. 


\section{INTRODUCTION}

The relationship between spirituality and economic life has been ineffaceable though the ages...Throughout history, spirituality and religion have been integral to economic activities (Kale, 2004, p. 97)

Religion is a significant part of daily life that affects consumer decisions and behaviors (Delener, 1994; Wilkes et al., 1986). Studies have found that religion impacts various attitudes and behaviors (Chen and Thang, 2013; Vitel et al., 2005), such as those regarding voting preference (Bruce, 2003), whom to marry (Marks, 2005), and ethical beliefs (Tittle and Welch, 1983; Weaver and Agle, 2002; Vitell et al., 2005). One topic that remains under-researched is the influence of religion on consumer behavior (Cutler, 1991; Lindbridge, 2006). For most of the $20^{\text {th }}$ century, religion and religiosity have been considered "taboo" topics in the field of consumer research (Hirschman, 1983; Mokhlis, 2006; Rindfleisch, Wong, and Burroughs, 2010), and their role in consumer behavior has not yet been fully acknowledged (Essoo and Dibb, 2004). The anathema associated with religion is partly due to its divisive potential in society and between societies (James et al., 2011). Nevertheless, religion is also considered a valued institution that disseminate and form conscientiousness in society (Brennan, 2011), and its influential nature for better or worse is unquestionable (Campbell, 2012; McCabe, et al., 2013). For example, in Australian society Christianity has been attributed with a key role in forming a key part of the Australian identity - its Judeo-Christian ethics (Brennan, 2011; Watts, 2009),

Within academia, few studies have investigated the impact of religion on consumer ethics (e.g., Arli and Tjiptono, 2013; Devonish et al., 2009; Vitell et al., 2005). The link between religiosity and specific questionable consumer behaviors needs to be examined, particularly in regard to consumers from non-western countries (Vitell and Paolillo, 2003). 
In the last decades, increasing numbers of marketing firms are expecting more of their profits coming from international sales. Failures to account for the effects of differences in consumers' across nation based ethical values will hinder a marketer's effort to expand internationally (McDonald, 1994; Singhapakdi et al., 1999; Topol and Sherman, 1994). Studies show individual culture affects consumers' ethical decision making (Ferrel and Gresham, 1985; Hunt and Vitell, 1986; Singhapakdi et al., 1999; Quah et al.. 2012). For example, digital piracy is most rampant in countries with emerging economies, such as China and Indonesia compared to countries with advance economies such as US and Australia (Chatzidakis and Mitussis, 2007; Bender and Wang, 2009; Wang et al., 2005). Countries with low average incomes are particularly vulnerable to digital piracy. In Indonesia, a report shows an overall loss of $95 \%$ of the market due to piracy in all forms (i.e., physical, internet, and mobile) (International Intellectual Property Alliance, 2012). It is estimated that approximately 6 million people in Indonesia engage in illegal downloads, costing record companies US\$1.65 million a day (The Jakarta Post, 2013). Interestingly, in these nonwestern countries there are higher percentages of people with religion compared to individuals in the western countries (Crabtree, 2010). While some studies have looked at either religious or non-religious consumers, rarely have the two groups been directly compared. To date, very few studies have explored the impact of moral philosophy and religiosity on consumer ethical beliefs in religious versus non-religious consumers. Understanding the impact of religiosity on consumer behavior is important because it may provide a basis for the socialization of values, which has been shown to influence consumer choice (Engel and Blackwell, 1982; Kahle, 1996).

In the debate between theists and atheists (Martin, 2002; Connor, 2002), some argue that morality requires belief in God while others argue that morality is subjective and can exist without belief in God (Maitzen, 2009; Ramsey, 1956). Interestingly, a study shows that 
Who is more ethical?

atheism increases in more developed countries, from just $0.4 \%$ in 1911 , while in $2011,22 \%$ of Australian chose the option 'no religion' on their census (Australian Bureau Statistic, 2013). Similarly, New Zealand data showed a rise of atheism from $30 \%$ in 2001 to $35 \%$ in 2006 (Australian Bureau Statistic, 2013). In contrast, poorer nations have the highest proportions of people who identify as religious and the numbers are increasing (Crabtree, 2010; Paul, 2009). For example, from just 9\% of the population in 1910, Christianity in Nigeria has grown to $63 \%$ today (MacDonald, 2011). More than $96 \%$ of individuals from developing countries such as Bangladesh, Niger, Yemen, Indonesia and Malawi have claimed that religion is an important part of their daily life (Crabtree, 201). This research extends other studies by Kennedy and Lawton (1998); Patwardhan et al. (2012); Singhapakdi et al. (2013); Vitell and Paolillo (2003); Vitell et al. (2005) and Vitell et al. (2007). These previous studies did not distinguish differences between extrinsic personal and social religiosity. Moreover, those studies did not compare differences between religious and non-religious consumers. The aim of the present study is to provide empirical evidence of the impact of religion on consumers' ethical beliefs. Thus, the present study has the following specific research objectives. The first research objective is to examine differences in moral ideologies and ethical beliefs among religious and non-religious consumers in Indonesia and Australia. This represents one of the first cross-national studies to compare consumer moral ideologies and consumer ethical beliefs among religious and non-religious consumers. The second research objective is to investigate the impact of moral ideologies and religiosity on consumers' ethical beliefs. The study contributes to the debate on the impact of moral ideologies and religiosity on consumer ethics and can assist managers and public policymakers in their effort to mitigate unethical consumer activities. 
Who is more ethical?

\section{LITERATURE REVIEW AND HYPOTHESIS DEVELOPMENT}

The theoretical framework for this study is based on the ethics position theory developed by Forsyth (1980), which suggests that moral ideologies are determined by idealism and relativism (Forsyth, 2008). This section presents a review of the literature on consumer ethics, moral ideologies (idealism and relativism), and religiosity (intrinsic and extrinsic). Subsequently, several hypotheses will be developed to address our second research objective which investigates the impact of moral ideologies and religiosity on consumer ethics.

\section{Consumer Ethics}

Consumer ethics can be defined as "the moral principles and standards that guide behavior of individuals or groups as they obtain, use and dispose of goods and services" (Muncy and Vitell, 1992, p. 298). Consumer attitudes toward unethical practices have received considerable attention from researchers over the last few decades (Vitell, 2003). Muncy and Vitell (1992) developed a consumer ethics scale that explores the extent to which consumers believe that certain behaviors are wrong. The scale examines consumer ethical beliefs regarding specific behaviors and consists of four dimensions: (a) actively benefiting from illegal activities (ACTIVE; e.g. drinking a can of soda in a store without paying for it), (b) passively benefiting at the expense of others (PASSIVE; e.g., not saying anything when the waitress miscalculates the bill in your favor), (c) actively benefiting from deceptive or questionable (but legal) practices (QUEST; e.g., not telling the truth when negotiating the price of a new automobile), and (d) no harm/no foul activities (NO HARM; e.g., spending over an hour trying on different dresses and then not purchasing any of them). Each of these behaviors has a different level of ethicality. Actively benefiting from illegal activities (i.e., ACTIVE behavior) is considered unethical in many contexts and is more likely to be perceived as illegal (Al-Khatib et al., 1997). Most consumers believe it is more ethical to 
Who is more ethical?

passively benefit from another's mistake (i.e., PASSIVE behavior) than to actively benefit from an illegal activity (ACTIVE behavior; Vitell and Paolillo, 2003). Furthermore, consumers believe that benefiting from questionable, but legal, activities (i.e., QUEST behavior) is more ethical than passively benefiting from another's mistake (i.e., PASSIVE behavior). No harm/no foul behaviors (i.e., NO HARM behaviors) are generally considered to be acceptable and more ethical than the other three types of behavior (ACTIVE, PASSIVE, and QUEST).

In 2005, Vitell and Muncy updated the scale by adding new items that are grouped into three distinct categories: (a) downloading/buying counterfeit goods (DOWNLOAD; e.g., downloading pirated software and purchasing counterfeit goods), (b) recycling/environmental awareness (RECYCLING; e.g., returning cans and bottles), and (c) performing good deeds toward others (GOOD; e.g., giving a larger-than-expected tip to a waiter). Unlike the other categories, the latter two categories (RECYCLE and GOOD) reflect positive, rather than negative, ethical behaviors. The present study employs this updated version of the consumer ethics scale (Vitell and Muncy, 2005).

\section{Moral Ideology}

Two key principles that serve as a moral guide for consumer ethical decision making are idealism and relativism (Forsyth, 1992; Rawwas et al., 2005). Moral idealists believe that morality guides action; for example, harming others should be avoided at all times because it is universally wrong (Forsyth, 1992). These individuals believe that moral behavior leads to positive consequences (Forsyth, 1980; Vitell et al., 2003). In contrast, relativism suggests that moral rules or standards are relative to the cultural context (Forsyth, 1992; Rawwas et al., 2005) and focuses on the consequences of behaviors (Vitell et al., 2003). These ethical ideologies may vary from person to person, and a particular ideology may have a larger 
influence in the lives of some individuals than others (Vitell et al., 2003). In addition, it is important to note that a relative emphasis on outcome versus principles (i.e., relativism) does not always reflect a lack of ethical standards (Ferrell et al., 1989; Hunt and Vitell, 1986, 1993; Vitell et al., 2003).

Decades of research have found that idealism and relativism have an important influence on consumer ethical decision making in cross-cultural settings, including the US and Thailand (Singhapakdi et al., 1994), Egypt and Lebanon (Rawwas et al., 1994), Hong Kong and North Ireland (Rawwas et al., 1995), the US and Egypt (Al-Khatib et al., 1997), the US and Malaysia (Singhapakdi et al., 1999), the US and Korea (Lee and Sirgy, 1999), the US and Turkey (Rawwas et al., 2005), Australia and Indonesia (authors removed for reviewing). These studies demonstrated that idealism was associated with greater levels of moral perception and unwillingness to engage in unethical practices than relativism (Rawwas et al., 1995 ) and that differences in perceptions may be linked to one's background or context (Forsyth et al. 2008; Forsyth, 1980).

Forsyth's works (Forsyth et al. 2008; Forsyth, 1980) found that people's perceptions of morality can be traced to variations in their intuitive, personal moral philosophies (also see Forsyth 1980). Idealistic individuals believe "desirable consequences can, with the right action, always be obtained" (Forsyth, 1980, p. 176), while relativistic individuals "reject the possibility of formulating or relying on universal moral rules when drawing conclusions about moral questions" (p. 175). Scholars assert that differences in consumer perspectives are link to a number of factors. For example, Jackson (2002) asserts that the relativistic perspective may be linked to a nation's level of economic development, where he contends that consumers in developed countries tend to be more idealistic and less relativistic than consumers in developing countries. More recent studies also suggest that perceptions of ethics may differ within a nation due to differences from two or more subcultures (Burmeister 
2013; Swaidan 2012). Finally, other existing works indicate that consumer ethics are also influenced by individual's cohort; for example, studies show that elderly consumers were more ethical than the younger ones (Muncy and Vitell 1992; Authors removed from reviewing; Rawwas et al., 1996). Therefore, there is strong evidence that an individual's background and context influences one's ethical perspective (Spiekermann 2015).

The consensus is that one's background strongly influences one's consumer ethics outlook. For example, in most non-western countries, individuals are shaped by title, prudence, and ultimate respect for seniority, and they are guided by formal rules and standards (Rawwas, 2001). In contrast, western countries encourage individual decision making, where rules and regulations are formulated only in case of necessity (Rawwas, 2001). Rawwas et al. (2005) found that consumers in Turkey were more idealistic than American consumers and were indifferent toward relativism. Religious persons are generally more conservative and less dominant than non-religious persons (Barton and Vaugh, 1976; Wilkes et al., 1986). Individuals in Saudi Arabia and Indonesia are primarily Muslim and more likely to adopt the ethical principles dictated in the Quran (Abeng, 1997; Forsyth et al., 2008). Together, these findings suggest that individuals from religious non-western countries are more idealistic than individuals from western countries. However, despite consumers' religiosity, studies have found that idealism was negatively related to consumer unethical beliefs while relativism was positively related to consumer ethical beliefs (Vitell and Paolillo, 2003; Rawwas, 1996; Vitell, 2003). Thus, we offer the following hypotheses:

$\mathrm{H}_{1}$ : For religious consumers in Indonesia, idealism is negatively related to: (a) actively benefiting; (b) passively benefiting; (c) questionable practices; (d) no-harm; (e) downloading and positively related to: (f) recycling; (g) doing good.

$\mathrm{H}_{2}$ : For religious consumers in Indonesia, relativism is positively related to: (a) actively benefiting; (b) passively benefiting; (c) questionable practices; (d) no-harm; (e) downloading and negatively related to: (f) recycling; (g) doing good. 
$\mathrm{H}_{3}$ : For religious consumers in Australia, idealism is negatively related to: (a) actively benefiting; (b) passively benefiting; (c) questionable practices; (d) no-harm; (e) downloading and positively related to: (f) recycling; (g) doing good.

$\mathrm{H}_{4}$ : For religious consumers in Australia, relativism is positively related to: (a) actively benefiting; (b) passively benefiting; (c) questionable practices; (d) no-harm; (e) downloading and negatively related to: (f) recycling; (g) doing good.

$\mathrm{H}_{5}$ : For non-religious consumers in Australia, idealism is negatively related to: (a) actively benefiting; (b) passively benefiting; (c) questionable practices; (d) no-harm; (e) downloading and positively related to: (f) recycling; (g) doing good.

$\mathrm{H}_{6}$ : For non-religious consumers in Australia, relativism is positively related to: (a) actively benefiting; (b) passively benefiting; (c) questionable practices; (d) no-harm; (e) downloading and negatively related to: (f) recycling; (g) doing good.

\section{Intrinsic and Extrinsic Religiosity}

Studies have found that religiosity has an important influence on personality and behavior (Gorsuch, 1988; Lau, 1989). Allport and Ross (1967) defined religious orientation as the extent to which a person lives out his or her religious beliefs. Religious motivations can be viewed in terms of intrinsic and extrinsic religiousness. Allport and Ross (1967) suggested that intrinsic religiousness and extrinsic religiousness could differentiate religious motivation (religiosity is synonymous with religiousness). The "extrinsically motivated person uses his religion, while intrinsically motivated person lives his religion" (Allport, 1950). Religion assumed different role in people's life. The extrinsic role represents the peripheral role of religions for personal contentment and or social approval. Thus, it is an indicative of having religious involvement for selfish reason and finding ways that religions might serve oneself (e.g. I go to a religious services because it helps me to make friends). In contrast, the intrinsic role represents a strong internal commitment to religion as part of daily life. Consequently, it also indicates having religious commitment for more inherent, spiritual objective and finding ways that one might serve one's religion (e.g., my whole approach to life is based on my religion) (Donahue, 1985; Vitell, 2009). Kirkpatrick and Hood (1990) suggested that extrinsic religiosity, as measured by Allport and Ross (1967), divided into two 
main categories, extrinsic personally oriented and extrinsic socially oriented. An individual with strong extrinsic religiosity might be more influenced by social determinants and participate in religious activities to meet personal needs (e.g., source of comfort and peace) or for social goals (e.g., social support). Vitell et al. (2003) found that religion plays an important ethical role in the contemporary life of the believer. Based on the Hunt-Vitell model (1986, 1993), religiosity influences consumer ethical beliefs in a positive way. Arli and Tjiptono (2013) found that intrinsic religiosity positively affected consumer ethics, while extrinsic social religiosity negatively affected consumer ethics. The stronger an individual's sense of intrinsic religiosity, the more likely he or she was to judge various 'questionable' consumer activities as wrong. From the religious point of view, God's law supersedes any other rules (Vitell et al., 2003). The consequences of "sinful" behavior often drive religious people to follow proscribed principles of virtue and morality (Vitell et al., 2003). McCabe and Trevino (1993) found that unethical behavior was negatively correlated with the severity of the punishment, including that related to the afterlife. Thus, there is a negative correlation between religiosity and willingness to engage in unethical behavior (Arli and Tjiptono, 2013; Kennedy and Lawton, 1998). In short, those who are more religious will have stronger ethical beliefs regarding specific ethical behaviors and actions (Arli and Tjiptono, 2013; Vitell et al., 2003). Thus, we offer the following hypotheses for the religious consumers:

$\mathrm{H}_{7}$ : In Indonesia, Intrinsic religiosity is negatively related to: (a) actively benefiting; (b) passively benefiting; (c) questionable practices; (d) no-harm; (e) downloading and positively related to: (f) recycling; (g) doing good.

$\mathrm{H}_{8}$ : In Australia, Intrinsic religiosity is negatively related to: (a) actively benefiting; (b) passively benefiting; (c) questionable practices; (d) no-harm; (e) downloading and positively related to: (f) recycling; ( $\mathrm{g}$ ) doing good.

Vitell et al. (2005) suggest that individuals with a high degree of extrinsic religiousness might not necessarily be committed to his/her religion as they might appear to be, thus, might not be ethically sensitive compared to individuals with high intrinsic 
religiousness. Singhapakdi et al. (2013) found that managers who are higher in terms of their extrinsic religiosity tend to be less ethical in their intention. Similarly, Arli and Tjiptono (2013) found that extrinsic religiosity negatively affect consumer ethical beliefs. Extrinsic religiosity is more situational since it is a form of utilitarian motivation thus it is less correlated with religious commitment (Donahue, 1985; Singhapakdi et al., 2013). Therefore, we will test the following hypotheses:

$\mathrm{H}_{9}$ : In Indonesia, Extrinsic personal religiosity is positively related to: (a) actively benefiting; (b) passively benefiting; (c) questionable practices; (d) no-harm; (e) downloading and negatively related to: (f) recycling; (g) doing good.

$\mathrm{H}_{10}$ : In Indonesia, Extrinsic social religiosity is positively related to: (a) actively benefiting; (b) passively benefiting; (c) questionable practices; (d) no-harm; (e) downloading and negatively related to: (f) recycling; (g) doing good.

$\mathrm{H}_{11}$ : In Australia, Extrinsic personal religiosity is positively related to: (a) actively benefiting; (b) passively benefiting; (c) questionable practices; (d) no-harm; (e) downloading and negatively related to: (f) recycling; (g) doing good.

$\mathrm{H}_{12}$ : In Australia, Extrinsic social religiosity is positively related to: (a) actively benefiting; (b) passively benefiting; (c) questionable practices; (d) no-harm; (e) downloading and negatively related to: (f) recycling; (g) doing good.

Figure 1 summarises the conceptual model of this study, that is, consumers' moral ideologies and consumers' religiosity as independent variables will influence consumers' ethical beliefs.

Insert Table 1 About Here

\section{METHODS}

\section{Measures}

Moral ideology was measured using ethics position questionnaires developed by Forsyth (1980). These consist of two scales, one designed to measure idealism (e.g., A person should make certain that their actions never intentionally harm another even to a small degree) and one that measures relativism (e.g., There are no ethical principles that are so important that they should be a part of any code of ethics). Respondents rated each behavior using a 5-point 
Likert-type scale ranging from $1=$ strongly disagree to $5=$ strongly agree. The Cronbach alphas for idealism and relativism were $\alpha=.71$ ( 4 items) and $\alpha=.70$ (6 items), respectively. Items with low factor scores $(<.50)$ were removed (Bryant and Yarnold, 1995). The study retained 4 items from the idealism construct: (1) a person should make certain that their actions never intentionally harm another even to a small degree; (2) one should never psychologically or physically harm another person; (3) if an action could harm an innocent other, then it should not be done; and (4) deciding whether or not to perform an act by balancing the positive consequences of the act against the negative consequences of the act is immoral) and 6 items from the relativism construct: (1) what is ethical varies from one situation and society to another. Moral standards should be seen as being individualistic; (2) what one person considers to be moral may be judged to be immoral by another person; (3) different types of moralities cannot be compared as to "rightness". (4) questions of what is ethical for everyone can never be resolved since what is moral or immoral is up to the individual; (5) moral standards are simply personal rules which indicate how a person should behave, and are not to be applied in making judgments of others; (6) ethical considerations in interpersonal relations are so complex that individuals should be allowed to formulate their own individual codes.

Religiosity was measured using the revised intrinsic/extrinsic religiosity scale adapted from Allport and Ross (1967) by Kirkpatrick (1990). The religious orientation scale is one of the most frequently used measures for determining the degree to which a person internalizes and practices religious beliefs and values (Donahue, 1985; Vitell et al., 2009). The intrinsic dimension is exemplified by items such as I try hard to live my life according to my religious beliefs. As previously discussed, extrinsic religiosity is divided into two categories: extrinsic personal and extrinsic social. Examples of extrinsic personal and extrinsic social items are: $I$ pray mainly to gain relief and protection and I go to religious services mostly to spend time 
with my friends, respectively. Respondents rated each behavior using a 5-point Likert-type scale ranging from $1=$ strongly disagree to $5=$ strongly agree. The reliabilities of the three dimensions, intrinsic religiosity, extrinsic personal religiosity, and extrinsic social religiosity, were $\alpha=.94$ (5 items), $\alpha=.85$ ( 3 items), and $\alpha=.92$ (3 items), respectively.

Consumer ethical beliefs were measured using the revised consumer ethics scale (Muncy and Vitell, 2005), which includes the seven dimensions of consumer behavior: ACTIVE, PASSIVE, QUEST, NO HARM, DOWNLOAD, RECYCLE, and GOOD. Respondents rated each behavior using a 5-point Likert-type scale ranging from $1=$ strongly disagree to $5=$ strongly agree. A high score on the scale indicates that consumers consider a particular action to be more ethical and acceptable. The reliabilities of the seven dimensions of the consumer ethics scale were as follows: ACTIVE, $\alpha=.82$ (5 items); PASSIVE, $\alpha=.85$ (5 items); QUEST, $\alpha=.86$ (5 items); NO HARM, $\alpha=.80$ (5 items); DOWNLOAD, $\alpha=.67$ (2 items); RECYCLE, $\alpha=.76$ (3 items); and GOOD, $\alpha=.64$ (4 items).

\section{Samples}

Australian sample. Australia has a population of 22 million and a relatively low rate of poverty (Population Reference Bureau, 2011). Approximately 62\% of Australians are Christian or Catholic, 2\% are Buddhist, 2\% are Muslim, 14\% are other/unspecified, and 20\% have no religion (The World Factbook, 2013). Data for this study was collected from undergraduate students at a large public university in Australia, their friends, and members of their immediate families. Students received credit points for participating in this study. Of 750 questionnaires, participants returned 691. Incomplete surveys with too many missing values were removed from the sample. Of these, 669 were usable, yielding a response rate of $89 \%$. 
Male and female respondents were almost equal in number (49\% and 51\%, respectively). Most participants were single (59\%), and 37\% were married. The age ranges were $18-24$ years $(52 \%), 25-34$ years $(21 \%), 35-44$ years $(7 \%), 45-54$ years $(11 \%)$, and 55 and above (9\%). In terms of religion, $40 \%$ of the respondents identified as Christian or Catholic, while 34\% reported having no religion. Those who declared of having no religion are categorized as the non-religious group while those who declared their religion are categorized as the religious group. Table 1 summarizes the demographic profiles of the respondents.

Indonesian sample. Indonesia is a country of cultural diversity and home to the largest Muslim population in the world; $88 \%$ of the population are Muslim, followed by $8 \%$ Christian or Catholic, 2\% Hindu, 1\% Buddhist, and 1\% other (The World Factbook, 2013). Indonesia is the fourth most populous nation in the world, with around 240 million people, and is the largest country in Southeast Asia (Population Reference Bureau, 2011). Unlike the situation in Australia, poverty is a widespread issue in Indonesia, where 32 million people live below the poverty line (World Bank, 2014). Indonesia's population is relatively young with an estimated median age of 23.06 with $30.6 \%$ of their working age population have completed their high school education for tertiary education at colleges or university (CEIC, 2013; World Bank, 2014). Data for this study was collected from undergraduate students at three large private universities in Surabaya, Indonesia. Surabaya is the second largest city in Indonesia with around 3 million inhabitants in 2011. This voluntary study was promoted in undergraduate classes by lecturers, who distributed 500 copies of the questionnaire to students. Participant returned 474, after removing incomplete questionnaires. The final number of respondents was 451 , yielding a response rate of $90 \%$. In terms of demographics, $65 \%$ of respondents were female and the age ranges were $18-24$ years $(88 \%), 25-34$ years $(8 \%), 36-44$ years $(3 \%)$, and 45 and above (1\%). In terms of religiosity, only $1 \%$ of 
respondents claimed to have no religion, while the largest religious group was Islam (30\%). The demographic profiles are summarized in Table 1.

Insert Table 1 here.

\section{RESULTS}

Based on demographic analysis, the samples were divided into three main groups: Indonesian religious consumers, Australian religious consumers, and Australian non-religious consumers. The questionnaire asked whether respondents considered themselves as a religious person or not.

To address the first objective of this study, which was to investigate the differences in consumer moral ideology and beliefs among religious and non-religious consumers in different cultures, a test of group mean differences (ANOVA) was employed to examine differences between the three groups (Indonesian religious consumers, Australian religious consumers, and Australian non-religious consumers) in terms of moral ideology (idealism and relativism) and ethical beliefs about various consumer behaviors (ACTIVE, PASSIVE, QUEST, NO HARM, DOWNLOAD, RECYCLE, and GOOD). Subsequently, Post-hoc tests were conducted to identify which group is significantly different.

In order to address the second objective of this study, several hypotheses were used to explore the effect of religiosity and consumer ideology on consumer ethical beliefs, multiple regression analysis was employed for each group (Indonesian religious consumers, Australian religious consumers, and Australian non-religious consumers). Idealism, relativism, intrinsic religiosity, extrinsic social religiosity, and extrinsic personal religiosity were the independent variables and the ethical beliefs of consumers in regard to the seven dimensions of the consumer ethics scale were the dependent variables. For the group of Australian nonreligious consumers, the three religiosity dimensions (intrinsic religiosity, extrinsic personal 
religiosity, and extrinsic social religiosity) were excluded from the analysis, as they were not applicable.

\section{Research Objective 1}

The first objective of this study was to investigate differences in consumer moral ideology and beliefs among religious and non-religious consumers in Indonesia and Australia. The results are shown in Table 2 and Figure 2-4.

In terms of moral ideology, there were significant differences in idealism between Indonesian religious consumers $(\mathrm{M}=4.20)$, Australian religious consumers $(\mathrm{M}=4.04)$, and Australian non-religious consumers $(\mathrm{M}=3.86)$, where Indonesian religious consumers displayed the highest degree of idealism among the three groups. However, the results revealed no significant differences in the degree of relativism between religious consumers in Indonesia, religious consumers in Australia, and non-religious consumers in Australia.

In terms of consumer ethical beliefs regarding ACTIVE behaviors, there was no significant difference between religious consumers in Indonesia $(M=2.30)$, religious consumers in Australia $(\mathrm{M}=2.20)$ and non-religious consumers in Australia $(\mathrm{M}=2.39)$. However, regarding PASSIVE there is a significant different between religious consumers in Indonesia (M=2.17) and both Religious consumers in Australia $(\mathrm{M}=2.56)$ and non-religious consumers in Australia (M=2.73).

Insert Table 2 and Figure 2-4 About Here

For the next three behaviors, QUEST, NO HARM, and GOOD, significant differences were found between all three groups. For consumer ethical beliefs regarding QUEST behaviors, there were significant differences between religious consumers in Indonesia $(M=2.16)$ and both religious and non-religious consumers in Australia $(M=2.54$ 
and $\mathrm{M}=2.76$, respectively) and significant differences between religious and non-religious consumers in Australia. The same significant results were found for consumer ethical beliefs regarding NO HARM behaviors (religious consumers in Indonesia, $\mathrm{M}=2.70$; religious consumers in Australia, $M=3.24$; non-religious consumers in Australia, $M=3.47$ ), and GOOD behaviors (religious consumers in Indonesia, $\mathrm{M}=3.93$; religious consumers in Australia, $\mathrm{M}=3.35$; non-religious consumers in Australia, $\mathrm{M}=3.15$ ).

In terms of consumer ethical beliefs regarding DOWNLOAD behaviors, the results showed significant differences between religious consumers in Indonesia $(M=3.36)$ and religious consumers in Australia $(M=3.12)$. In addition, significant differences were found between religious consumers in Australia and non-religious consumers in Australia $(\mathrm{M}=$ 3.37). However, no significant differences were found between religious consumers in Indonesia and non-religious consumers in Australia.

In terms of consumer ethical beliefs regarding RECYCLE behaviors, the results showed significant differences between religious consumers in Indonesia $(M=3.51)$ and both religious and non-religious consumers in Australia $(\mathrm{M}=3.02$ and $\mathrm{M}=3.03$, respectively) but no significant difference between religious and non-religious consumers in Australia.

\section{Research Objective 2}

The second objective of this study was to investigate the impact of religiosity and consumer ideology on consumer ethical beliefs in the three groups (Indonesian religious consumers, Australian religious consumers, and Australian non-religious consumers). In addition to consumers' religiosity, the results need to be distinguished between Indonesian and Australian consumers, as there are differences on consumers' attitude toward downloading and recycling between Indonesians and Australians. A report shows that over $91 \%$ of Australian household claimed they practice some form of waste recycling (Australian 
Who is more ethical?

Bureau of Statistic, 2010). Moreover, in regards to software piracy in Indonesia, the Business Software Alliance (BSA, 2011) reported that $86 \%$ of software in Indonesia is pirated, resulting in a loss of US\$1.46 billion per year. Students represent a major consumer segment for digital piracy, which is prevalent in academia (Gopal and Sanders, 2000; Wang et al., 2005). This ranks Indonesia among the top three countries in terms of piracy rates, along with Venezuela (88\%) and China (77\%) (Fitzgerald, 2012). Thus, by separating Indonesia and Australia, this study may provide specific contributions toward consumers' ethics. Tables 3, 4, and 5 show the correlation matrices for independent and dependent variables for Indonesian religious consumers, Australian religious consumers, and Australian non-religious consumers, respectively. Tables 6,7 , and 8 show the results of multiple regression analysis for Indonesian religious consumers, Australian religious consumers, and Australian nonreligious consumers, respectively. Prior to interpreting the result, several assumptions were evaluated. First, stem-and-leaf plots and boxplots in this study indicated that each variable in the regression was normally distributed. They are all roughly symmetrical and bell shaped (Allen and Bennet, 2012; Tabachnick and Fidell, 2001). Second, inspection of the normal probability plot of standardized residuals as well as the scatterplot of standardized residuals indicated that the assumption of normality, linear and homoscedasticity of residual were met. The point clustered reasonably tightly along the diagonal line indicated the residuals are normally distributed. Moreover, Homoscedasticity can be checked by visual examination of a plot of the standardized residuals by the regression standardized predicted value (Osborne and Waters, 2002). The absence of clear patterns in the spread points also indicated that these assumptions have been met. Mahalanobis distance mean score were 4.99 which did not exceed the critical $x^{2}$ for $\mathrm{df}=5$ (at $\alpha=0.001$ ) of 20.52 (Allen and Bennet, 2012; Hair, 2010), the results shows that multivariate outlier were not of concern. Finally, relatively high tolerance and low VIF $(0.440-2.3)$ for the predictors in the regression model indicates that 
multicollinearity would not influence the ability to interpret the outcome of the regression model (Keith, 2006).

Indonesian religious consumers. The results in Table 6 show that idealism had a negative impact on consumer ethical beliefs regarding ACTIVE behaviors $(\beta=-0.129 ; p<$ $0.01)$, PASSIVE behaviors $(\beta=-0.151 ; \mathrm{p}=0.001)$, QUEST behaviors $(\beta=-0.170 ; p<$ $0.001)$, and NO HARM behaviors $(\beta=-0.179 ; p<0.001)$ and a positive impact on consumer ethical beliefs regarding GOOD behaviors $(\beta=0.118 ; p<0.01)$. Thus, $\mathrm{H}_{1 \mathrm{a}}, \mathrm{H}_{1 \mathrm{~b}}, \mathrm{H}_{1 \mathrm{c}}, \mathrm{H}_{1 \mathrm{~d}}$ and $\mathrm{H}_{1 \mathrm{~g}}$ are supported. However, idealism had no effect on consumer beliefs regarding DOWNLOAD or RECYCLE behaviors. Therefore, $\mathrm{H}_{1 \mathrm{e}}$ and $\mathrm{H}_{1 \mathrm{f}}$ are not supported. Furthermore, the results in Table 6 also show that relativism had a positive impact on consumer beliefs regarding ACTIVE behaviors $(\beta=0.116 ; p<0.01)$, PASSIVE behaviors $(\beta$ $=0.120 ; p<0.01)$, and QUEST behaviors $(\beta=0.150 ; p<0.001)$. Therefore, $\mathrm{H}_{2 \mathrm{a}}, \mathrm{H}_{2 \mathrm{~b}}$ and $\mathrm{H}_{2 \mathrm{c}}$ are supported. However, relativism had no effect on consumer ethical beliefs regarding NO HARM, DOWNLOAD, RECYCLE, and GOOD behaviors. Thus, $\mathrm{H}_{2 \mathrm{~d}}, \mathrm{H}_{2 \mathrm{e}}, \mathrm{H}_{2 \mathrm{f}}$ and $\mathrm{H}_{2 \mathrm{~g}}$ are not supported.

In regards to religiosity, intrinsic religiosity had a negative impact on consumer ethical beliefs regarding ACTIVE behaviors $(\beta=-0.166 ; p<0.001)$, PASSIVE behaviors $(\beta$ $=-0.258 ; p<0.001)$, QUEST behaviors $(\beta=-0.255 ; p<0.001)$, and NO HARM behaviors $(\beta$ $=-0.209 ; p<0.001)$ and a positive impact on RECYCLE behaviors $(\beta=0.130 ; p<0.01)$. Therefore, $\mathrm{H}_{7 \mathrm{a}}, \mathrm{H}_{7 \mathrm{~b}}, \mathrm{H}_{7 \mathrm{c}}, \mathrm{H}_{7 \mathrm{~d}}$ and $\mathrm{H}_{7 \mathrm{f}}$ are supported. However, intrinsic religiosity did not significantly affect consumer ethical beliefs regarding DOWNLOAD and GOOD behaviors. Hence, $\mathrm{H}_{7 \mathrm{e}}$ and $\mathrm{H}_{7 \mathrm{~g}}$ are not supported.

Extrinsic personal religiosity had a positive impact on consumer ethical beliefs regarding ACTIVE behaviors $(\beta=0.107 ; p<0.05)$, RECYCLE behaviors $(\beta=0.110 ; p<$ $0.05)$, and GOOD behaviors $(\beta=0.166 ; p<0.01)$. Hence, $\mathrm{H}_{9 \mathrm{a}}$ is supported. However, $\mathrm{H}_{9 \mathrm{f}}$ and 
$\mathrm{H}_{9 \mathrm{~g}}$ are not supported due to the opposite direction of the results. Moreover, extrinsic personal religiosity had no effect on PASSIVE, QUEST, NO HARM, or DOWNLOAD behaviors. Thus, $\mathrm{H}_{9 b}, \mathrm{H}_{9 c}, \mathrm{H}_{9 d}$ and $\mathrm{H}_{9 \mathrm{e}}$ are not supported.

Finally, extrinsic social religiosity had a positive impact on consumer ethical beliefs regarding ACTIVE behaviors $(\beta=0.184 ; p<0.001)$, PASSIVE behaviors $(\beta=0.173$; $p<$ 0.001), QUEST behaviors $(\beta=0.099 ; p<0.05)$, and NO HARM behaviors $(\beta=0.150 ; p<$ 0.001). Therefore, $\mathrm{H}_{10 \mathrm{a}}, \mathrm{H}_{10 \mathrm{~b}}, \mathrm{H}_{10 \mathrm{c}}$ and $\mathrm{H}_{10 \mathrm{~d}}$ are supported. However, extrinsic social religiosity had no effect on consumer ethical beliefs regarding DOWNLOAD, RECYCLE, or GOOD behaviors. Hence, $\mathrm{H}_{10 \mathrm{e}}, \mathrm{H}_{10 \mathrm{f}}$ and $\mathrm{H}_{10 \mathrm{~g}}$ are not supported.

Australian religious consumers. The results in Table 7 show that idealism had a negative impact on consumer ethical beliefs regarding ACTIVE behaviors $(\beta=-0.173 ; p<$ 0.001), PASSIVE behaviors $(\beta=-0.147 ; p<0.001)$ and QUEST behaviors $(\beta=-0.193 ; p<$ 0.001). Therefore, $\mathrm{H}_{3 \mathrm{a}}, \mathrm{H}_{3 \mathrm{~b}}$, and $\mathrm{H}_{3 \mathrm{c}}$ are supported. However, idealism had no effect on consumer ethical beliefs regarding QUEST behavior, NO HARM, RECYCLE and GOOD behaviors. Thus, $\mathrm{H}_{3 \mathrm{~d}}, \mathrm{H}_{3 \mathrm{e}}, \mathrm{H}_{3 \mathrm{f}}$ and $\mathrm{H}_{3 \mathrm{~g}}$ are not supported. Moreover, the results in Table 7 also show that relativism had a positive impact only on consumer ethical beliefs regarding QUEST behaviors $(\beta=0.048 ; p<0.05)$ and negative impact on GOOD behavior $(\beta=-1.806$; $p<0.05)$. Hence, $\mathrm{H}_{4 \mathrm{c}}$ and $\mathrm{H}_{4 \mathrm{~g}}$ are supported. Nonetheless, relativism had no effect on consumer ethical beliefs regarding ACTIVE, PASSIVE, NO HARM, DOWNLOAD and RECYCLE. Therefore, $\mathrm{H}_{4 \mathrm{a}}, \mathrm{H}_{4 \mathrm{~b}},{ }_{4 \mathrm{~d}}, \mathrm{H}_{4 \mathrm{e}}$, and $\mathrm{H}_{4 \mathrm{f}}$ are not supported.

In regards to religiosity, intrinsic religiosity had a negative impact on consumer ethical beliefs regarding ACTIVE behaviors $(\beta=-0.183 ; p<0.005)$, PASSIVE behaviors $(\beta$ $=-0.233 ; p<0.05)$, QUEST behaviors $(\beta=-0.263 ; p<0.05)$, NO HARM behaviors $(\beta=$ 0.201; $p<0.05)$; DOWLOAD $(\beta=-0.140 ; p<0.05)$, and a positive impact on consumer ethical beliefs regarding and GOOD behaviors $(\beta=0.257 ; p<0.001)$. Hence, $\mathrm{H}_{8 \mathrm{a}}, \mathrm{H}_{8 \mathrm{~b}}, \mathrm{H}_{8 \mathrm{c}}$, 
$\mathrm{H}_{8 \mathrm{~d}} . \mathrm{H}_{8 \mathrm{e}}$, and $\mathrm{H}_{8 \mathrm{~g}}$ are supported. However, intrinsic religiosity had no impact on RECYCLE. Thus, $\mathrm{H}_{8 \mathrm{f}}$ is not supported. Furthermore, extrinsic personal religiosity had no effect on all consumer ethical beliefs (i.e. ACTIVE, PASSIVE, QUEST, NO HARM, DOWNLOAD, RECYCLING AND GOOD). Thus, $\mathrm{H}_{11 \mathrm{a}}, \mathrm{H}_{11 \mathrm{~b}}, \mathrm{H}_{11 \mathrm{c}}, \mathrm{H}_{11 \mathrm{~d}}, \mathrm{H}_{11 \mathrm{e}}, \mathrm{H}_{11 \mathrm{f}}$ and $\mathrm{H}_{11 \mathrm{~g}}$ are not supported. Finally, extrinsic social religiosity had a positive impact on consumer ethical beliefs regarding ACTIVE behaviors $(\beta=0.155 ; p<0.05)$ and QUEST behaviors $(\beta=0.106$; $p<0.01$ ). Hence, $\mathrm{H}_{12 \mathrm{a}}$, and $\mathrm{H}_{12 \mathrm{c}}$ are supported. However, extrinsic social religiosity had no effect on consumer ethical beliefs regarding PASSIVE, NO HARM, DOWNLOAD, and RECYCLE and GOOD behaviors. Therefore, $\mathrm{H}_{12 \mathrm{~b}}, \mathrm{H}_{12 \mathrm{~d}}, \mathrm{H}_{12 \mathrm{e}}, \mathrm{H}_{12 \mathrm{f}}$ and $\mathrm{H}_{12 \mathrm{~g}}$ are not supported.

Australian non-religious consumers. As previously mentioned, religiosity dimensions were not included in the analysis for this group as they are irrelevant to non-religious individuals. The results in Table 8 show that idealism had no significant effect on consumer all ethical beliefs regarding ACTIVE, PASSIVE, QUEST, NO HARM, DOWNLOAD, RECYCLE, or GOOD behaviors. Thus, $\mathrm{H}_{5 \mathrm{a}}, \mathrm{H}_{5 \mathrm{~b}}, \mathrm{H}_{5 \mathrm{c}}, \mathrm{H} 5 \mathrm{~d}, \mathrm{H}_{5 \mathrm{e}}, \mathrm{H}_{5 \mathrm{f}}$ and $\mathrm{H}_{5 \mathrm{~g}}$ are not supported. Similarly, relativism had no effect on consumer ethical beliefs regarding any of the seven dimensions of consumer behavior. Therefore, $\mathrm{H}_{6 \mathrm{a}}, \mathrm{H}_{6 \mathrm{~b}}, \mathrm{H}_{6 \mathrm{c}}, \mathrm{H}_{6 \mathrm{~d}}, \mathrm{H}_{6 \mathrm{e}}, \mathrm{H}_{6 \mathrm{f}}$ and $\mathrm{H}_{6 \mathrm{~g}}$ are not supported

Insert Table 3-8 About Here

\section{DISCUSSION}

The study contributes to the ethics position theory developed by Forsyth (1980). As previously discussed, idealism is associated with greater ethicality while relativism with lower ethicality. This study argues that in addition to moral ideologies, consumers are being influenced by their religion. The two concepts (i.e. moral ideologies and religion) are often 
Who is more ethical?

inseparable especially for a religious individual. This study indicates that religion is often a stronger predictor than consumers' moral ideologies on consumer ethical beliefs, especially when the issue falls into the grey area category and/or existing guidelines are unclear. Our findings showed that when issues clearly violates legal statute and/or involves dishonesty individuals who have religious and non-religious backgrounds are more likely to hold strong ethical stance. However, when the issues involve a new or grey area and/or existing guidelines are unclear (e.g., passive, questionable, no harm, downloading) religious convictions are more likely to be stronger predictors of consumer ethical beliefs. At the same time religious convictions also appear to be a strong predictor of socially desirable behaviors (doing good).

These findings highlight the importance of values in decision-making and for consumers. Hunt and Vitell (1993, p. 780) suggest, “Unquestionably, an individual's personal religion influences ethical decision-making. A priori, compared with nonreligious people, one might suspect that the highly religious people would have more clearly defined deontological norms and that such norms would play a stronger role in ethical judgments". Moreover, our findings do suggest that in cases where there is a new or grey area, and/or where existing guidelines are unclear those with religious convictions appear to have gone beyond a deontological approach, thus made ethical choices where the legal statute may be unclear. This suggests that those who are religious may be better prepared towards developing higher levels of cognitive moral development (i.e., post-conventional), thus improving their capacity to undertake moral decisions and actions (Kohlberg, 1969; 1984).

This study also extends various studies on the impact of religiosity on consumers ethics (e.g., Vitell et al., 2007; Kennedy and Lawton, 1998; Patwardhan et al., 2012; Singhapakdi et al., 2013; Vitell and Paolillo, 2003; Vitell et al. 2005; Vitell et al., 2007). Most of these studies did not distinguish differences between extrinsic personal and social 
Who is more ethical?

religiosity. In addition, previous research failed to explore the differences between religious and non-religious consumers' moral ideologies ethical beliefs. The results of this study are able fill these gaps.

For religious consumers, they were found to rank negative consumer behaviors as being more unethical compared to non-religious consumers. In terms of religiosity, the present study found that intrinsic religiosity was associated with a stronger belief that negative consumer activities were unethical, and this relationship held true among religious consumers in both Indonesia and Australia. However, extrinsic social was associated with a stronger belief that negative consumer activities were acceptable, while extrinsic personal religiosity has no effect on most consumer ethical beliefs. It shows that appearance of religious activities (extrinsic dimension: being active in a church) may not translate to more ethical behavior. Religious communities and leaders, therefore, can play an influential role especially in the lives of individuals with extrinsic motives for religion that is, emphasizing the importance of religion and committing it to their daily life beyond receiving perks and benefits of joining a religious community. Again we assert that instilling commitment to religious values may prepare individuals towards developing their capacity to undertake moral decisions and actions (Kohlberg, 1969; 1984). These results are consistent with those of Vitell et al. (2007) and suggest that religiosity plays an important role in consumer ethical decision making in both developed and developing countries. Studies involving consumer religions should distinguish between intrinsic, extrinsic personal and extrinsic social as they reveal different impact on consumer ethics. In addition, intrinsic religiosity has stronger effects than moral ideology (i.e. idealism) on most consumer ethical beliefs.

In regards to non-religious consumers, these results suggest that non-religious consumers are unaware that many of these negative, but legal, behaviours are unethical and illustrate the importance of providing clear ethical guidelines to non-religious consumers. 
Governments should collaborate with ethical institutions to educate consumers on the importance of being an ethical individual. For example, providing formal courses on ethics to students, increasing public awareness through media, and informal training may help an individual make better decisions in the context of questionable consumer behaviours.

Our results, shows an interesting cultural differences between developed and developing countries in the context of software piracy. In summary, being religious in Australia makes one less likely to approve of downloading whereas non-religious people in Australia had the same attitude as religious consumers in Indonesia, that is they still do it. This suggests that in the context of developed countries, there is a general attitude that digital piracy is acceptable, but religion may serves to mediate that belief. At the same time, Jackson's (2002) work may provide some light on this finding, namely, that a nation's level of economic development may also influence the rate of inappropriate downloading of music from the internet, especially when it is readily available. Research for the better part of two decades have supported this argument (cf: Burke, 1996; Silva and Ramello, 2000; Banerjee et al., 2005), that is, nations with higher levels of economic development correspond with lower levels of piracy.

\section{Managerial Implications and limitations}

This finding has implications for public policy makers and religious leaders; for example, maintaining religious studies in faith-based schools (e.g., Anglican schools, Islamic schools) may help to instill strong ethical beliefs against undesirable consumer behaviours among pupils. Alternatively, in non-faith-based schools, including ethical education in the curriculum may replace the religiosity domain that is inherent to faith-based schools in order to foster stronger ethical beliefs against negative consumer behaviours. 
In regard to Indonesia, this study found that intrinsic religiosity did not influence consumer beliefs regarding the ethicality of downloading pirated software. This can be explained by the fact that Indonesian consumers perceive these activities as acceptable (Business Software Alliance, 2011), which is why rates of digital and software piracy are extremely high in Indonesia, especially among young consumers. Banerjee et al.'s (2005) work also suggests that Indonesia's socio-economic environment with existing high corruption levels, lack of social and civil rights may be a contributing factor to such

behaviours. Our findings suggests that religion may not be not enough to overcome people's acceptance of this practice, alternatively, it is perceived as a victimless act. As such, the Indonesian government, business communities, and religious institutions need to educate people about intellectual property rights and the impact of piracy on Indonesian music, film, publishing, and other creative industries. In addition, given the importance of religion in Indonesia (100\% religious affiliation) and other developing nations (e.g., Bangladesh, Niger, Yemen, and Malawi) religious leaders can play a very important social role and emphasize that pirating is an act of stealing, which is incongruent with the values espoused by most religions and unethical (Brennan, 2011; Watts, 2009). This effort may help reduce the prevalence of digital piracy in Indonesia, which is currently amongst the highest in the world at $86 \%$ piracy rate. The same can be said for Australia which has an $80 \%$ religious population (Australian Bureau Statistic 2013), in that the role of religious communities and leaders to stem pirating of software in Australia is prominent.

Finally, limitations are inevitable in any convenience sampling. First, our samples derived from one population in one city for both Indonesia and Australia. In the Indonesian sample, most respondents are college students. They are a representative of Indonesian consumers in regards to age. However, our samples are more educated than the general population. As previously mentioned, only $30.6 \%$ of working age population have completed 
their high school education or tertiary education at colleges or university (CEIC, 2013; World Bank, 2014). Moreover, our sample did not represent the religious demographic of Indonesia where $88 \%$ of the populations are Muslim. Future research should obtain data from other demographic categories (i.e., age, income, education and ethnicity) and in other cities, especially in Indonesia, which may produce more generalizable results. Second, this study did not examine differences between each religion (i.e. Islam, Christian/ Catholic, Buddhism, Hinduism) which may produce different results. Moreover, this study is based on consumers' self-perception of their religiosity. We are focusing on consumers' religiosity which may be different to spirituality. Religion usually represents linkages with a specific doctrine of group of people while spirituality often used to refer to the broader concept of personal experience (Berry, 2005; Mytko and Night, 1999). It might be the case that they don't considered themselves as religious individuals (not belonging to a specific religious doctrine) but they are very spiritual. The difference between religiosity and spirituality may warrant future research. Third, in the regression analysis, the r-square and adjusted r-square values are low, between $0.002-0.159$. It shows there are other predictors that have not been considered. Future research may test other variables such as Machiavellianism, self-concept to identify factors affecting consumer ethical beliefs. Finally, the results show a future research opportunity for investigating factors that contribute to consumer ethical beliefs among nonreligious consumers. 


\section{REFERENCES}

Abeng, T. 1997. Business ethics in Islamic context: Perspectives of a Muslim business leader. Business Ethics Quarterly, 47-54.

Allen, P., Bennett, K. (2012). SPSS statistics: A practical guide version 20. Cengage Learning Australia.

Al-Khatib, J. A., Vitell, S. J., \& Rawwas, M. Y. 1997. Consumer ethics: a cross-cultural investigation. European Journal of Marketing, 31(11/12), 750-767.

Allport, G. W., Ross, J. M. 1967. Personal religious orientation and prejudice. Journal of Personality and Social Psychology, 5, 447-457.

Arli, D., Tjiptono, F. 2013. The End of Religion? Examining the Role of Religiousness, Materialism, and Long-Term Orientation on Consumer Ethics in Indonesia. Journal of Business Ethics, 1-16.

Australian Bureau of Statistic. 2010. Household recycling. Available at http://www.abs.gov.au/ausstats/abs@.nsf/Lookup/by\%20Subject/1370.0 2010 Chapt er Household\%20recycling\%20(6.6.7.1) (Accessed on 29 May 2014).

Australian Bureau of Statistic. 2013. Australian Social Trends. Available at http://www.abs.gov.au/ausstats/abs@.nsf/Lookup/4102.0Main+Features30Nov+2013 (Accessed 25 April 2016).

Banerjee, D., Khalid, A. M., Sturm, J-E. 2005. Socio-economic development and software piracy. An empirical assessment. Applied Economics, 37, 2091-2097.

Barton, K., Vaughan. G.1976. Church Membership and Personality. Social Behavior and Personality. 4, 11-16.

Bender, M. T., Wang, Y. (2009). The impact of digital piracy on music sales: A cross-country analysis. International Social Science Review, 84(3/4), 157-170.

Berry, D. 2005. Methodological pitfalls in the study of religiosity and spirituality. Western Journal of Nursing Research, 27(5), 628-647.

Brennan, F. 2011. The role of religious faith in modern society: a renewed vision. Ethics in a multi faith society: Muslims and Christians in dialogue. Conference under the auspices of the Fethullah Gulen Chair in the study of Islam and Muslim-Catholic Relations, Australian Catholic University, Melbourne, 23 November 2011. Retrieved on 17/06/2014. http://www.eurekastreet.com.au/article.aspx?aeid=29193\#.U5$1 \mathrm{TfmSx} 8 \mathrm{E}$.

Bruce, S. 2003. Politics and religion. Polity.

Burmeister, O.K. 2013. Achieving the goal of a global computing code of ethics through an international-localisation hybrid, Ethical Space: The International Journal of Communication Ethics, 10(4), 25-32.

Burke, A. E. (1996) How effective are international copyright conventions in the music industry?, Journal of Cultural Economics, 20, 51-66.

Business Software Alliance (BSA) - Ninth Annual BSA Global Software (2011). Piracy Study. Available at: http://portal.bsa.org/globalpiracy2011/ (accessed on 3 March 2013).

Bryant, F. B., Yarnold, P. R. 1995. Principal components analysis and exploratory and confirmatory factor analysis. In L. G. Grimm \& P. R. Yarnold (Eds.), Reading and understanding multivariate analysis. Washington, DC: American Psychological Association.

Campbell, H. A. 2012. Understanding the relationship between religion online and offline in a networked society. Journal of the American Academy of Religion, 80(1), 64-93. 
CEIC. 2013. Developing Indonesian Youthful Population. Available at: http://www.ceicdata.com/en/blog/developing-indonesia\%E2\%80\%99s-youthfulpopulation (accessed on 29 May 2014).

Chatzidakis, A., Mitussis, D. 2007. Computer ethics and consumer ethics: the impact of the internet on consumers' ethical decision-making process. Journal of Consumer Behaviour, 6(5), 305-320.

Chen, Y. J., \& Tang, T. L. P. 2013. The bright and dark sides of religiosity among university students: Do gender, college major, and income matter? Journal of Business Ethics, 115(3), 531-553.

Connors, R. B. 2002. Christian Morality: In the Breath of God. Loyola Press.

Cornwell, B., Cui, C. C., Mitchell, V., Schlegelmilch, B., Dzulkiflee, A., Chan, J. 2005. A cross-cultural study of the role of religion in consumers' ethical positions. International Marketing Review, 22(5), 531-546.

Crabtree, S. 2010. Religiosity highest in World's Poorest Nations. Available at: http://www.gallup.com/poll/142727/religiosity-highest-world-poorest-nations.aspx (accessed on 2 February 2014).

Cutler, B. 1991. Religion and marketing: important research area or a footnote in the literature? Journal of Professional Services Marketing, 8(1).

Delener, N. 1994. Religious contrasts in consumer decision behaviour patterns: their dimensions and marketing implications. European Journal of Marketing, 28(5), 3653.

Donahue, M .J. 1985. Intrinsic and extrinsic religiousness: Review and meta-analysis. Journal of Personality and Social Psychology, 48(2), 400-419.

Devonish, D., Alleyne, P. A., Cadogan-McClean, C., Greenidge, D. 2009. An empirical study of future professionals' intentions to engage in unethical business practices. Journal of Academic Ethics, 7(3), 159-173.

Erffmeyer, R. C., Keillor, B. D., LeClair, D. T. 1999. An empirical investigation of Japanese consumer ethics. Journal of Business Ethics, 18(1), 35-50.

Essoo, N., Dibb, S. 2004. Religious influences on shopping behaviour: an exploratory study. Journal of Marketing Management, 20(7-8), 683-712.

Ferrell, O. C., Gresham, L. G. 1985. A contingency framework for understanding ethical decision making in marketing. Journal of marketing, 49(3).

Ferrell, O. C., Gresham, L. G., Fraedrich, J. 1989. A synthesis of ethical decision models for marketing. Journal of Macromarketing, 9(2), 55-64.

Fitzgerald, B. 2012. Software piracy: study claims 57 percent of the world pirates software. Retrieved from: http://www.huffingtonpost.com/2012/06/01/software-piracy-studybsa n 1563006.html (Accessed on 29 May 2014).

Forsyth, D. R. 1980. A taxonomy of ethical ideologies. Journal of Personality and Social psychology, 39(1), 175.

Forsyth, D. R. 1992. Judging the morality of business practices: The influence of personal moral philosophies. Journal of Business Ethics, 11(5-6), 461-470.

Forsyth, D. R., O’Boyle Jr, E. H., McDaniel, M. A. 2008. East meets west: A meta-analytic investigation of cultural variations in idealism and relativism. Journal of Business Ethics, 83(4), 813-833.

Geyer, A. L., Baumeister, R. F. 2005. Religion, Morality, and Self-Control. In F. P. Raymond and L.P Crystal (eds). The Handbook of Religion and Religiosity (The Guilford Press, New York), pp. 412-432.

Gopal, R. D., Sanders, G. L. 2000. Global software piracy: you can't get blood out of a turnip. Communications of the ACM, 43(9), 82-89.

Gorsuch, R. L. 1988. Psychology of religion. Annual review of psychology, 39(1), 201-221. 
Hair, J. F. (2010). Multivariate data analysis. Pearson Education.

Hassan, L., Shaw, D., Shiu, E., Walsh, G., Parry, S. 2013. Uncertainty in ethical consumer choice: a conceptual model. Journal of Consumer Behaviour, 12(3), 182-193.

Hirschman, E. C. 1983. Religious affiliation and consumption processes: an initial paradigm. Research in marketing, 6, 131-170.

Hunt, S. D., Vitell, S. 1986. A general theory of marketing ethics. Journal of Macromarketing, 6(1), 5-16.

Hunt, S. D., Vitell, S. J. 1993. The General Theory of Marketing Ethics: A Retrospective and Revision. Ethics in Marketing (Irwin Inc., Homewood, IL), 775-784.

International Intellectual Property Alliance. 2012. Special Report of Copyright Protection and Enforcement. Retrieved from: http://www.iipa.com/rbc/2012/2012SPEC301INDONESIA.PDF

Jackson, T. 2002. The management of people across cultures: valuing people differently. Human Resource Management, 41(4), 455-475

James, W., Griffiths, G., Pederson, A. 2011. The "making and unmaking" of prejudice against Australian Muslims and gay men and lesbians: The role of religious development and fundamentalism. The International Journal for the Psychology of Religion, 21, 212-227.

Kahle, L. R. 1996. Social Values and Consumer Behavior: Research from the List of Values. In: Seligman, C., Olson, J.M., \& Zanna, M.P., editors. The Psychology of Values: The Ontario Symposium, 8, 131-151.

Kale, S.H. 2004. Spirituality, religion and globalization. Journal of Macromarketing, 24(2), 92-107.

Keith, T. (2006). Multiple regression and beyond. PEARSON Allyn \& Bacon.

Kennedy, E. J., Lawton, L. 1998. Religiousness and business ethics. Journal of business ethics, 17(2), 163-175.

Kirkpatrick, L. A., Hood Jr, R. W. 1990. Intrinsic-extrinsic religious orientation: The boon or bane of contemporary psychology of religion? Journal for the scientific study of religion, 442-462.

Kohlberg, L. 1969. Stage and sequence: The cognitive developmental approach to socialization. In D. A. Goslin (Ed.), Handbook of socialization theory. Chicago, IL: Rand McNally.

Kohlberg, L. 1984. Philosophy of moral development. New York, NY: Harper \& Row.

Lau, S. 1989. Religious schema and values. International Journal of Psychology, 24(1-5), 137-156.

Lee, D. J., Sirgy, M. J. 1999. The Effect of Moral Philosophy and Ethnocentrism on Qualityof-Life Orientation in International Marketing: A Cross-Cultural Comparison. Journal of Business Ethics, 18(1), 73-89.

Lindbridge, A. 2005. Religiosity and the construction of a cultural-consumption identity. Journal of Consumer Marketing, 22(3), 142-151.

Maitzen, S. 2009. Ordinary morality implies atheism. European Journal for Philosophy of Religion, 1(2), 107-126.

Marks, L. 2005. How does religion influence marriage? Christian, Jewish, Mormon, and Muslim perspectives. Marriage \& family review, 38(1), 85-111.

Martin, M. 2002. Atheism, morality, and meaning. Prometheus Books.

McCabe, M. P., Waqa, G., Dev, A. Cama, T., Swinburn, B. A. 2013. The role of cultural values and religion on views of body size and eating practices among adolescents from Fiji, Tonga, and Australia. British Journal of Health Psychology, 18, 383-394.

McCabe, D. L., Trevino, L. K. 1993. Academic dishonesty: Honor codes and other contextual influences. Journal of Higher Education, 522-538. 
McDonald, W.J. 1994.Developing international direct marketing strategies with a consumer decision-making content analysis. Journal of Direct Marketing, 8, 4, 18-27.

MacDonald, J. 2011. Study: Christianity grows exponentially in Africa. Source: http://usatoday30.usatoday.com/news/religion/story/2011-12-20/christianity-growthafrica-europe/52125920/1. (Accessed: 15 April 2016).

McDonald, G. 2010. Ethical relativism vs absolutism: research implications. European Business Review, 22(4), 446-464.

Mokhlis, S. 2006. The effect of religiosity on shopping orientation: An exploratory study in Malaysia. Journal of American Academy of Business, 9, 64-74.

Mytko, J. J., Knight, S. J. 1999. Body, mind and spirit: towards the integration of religiosity and spirituality in cancer quality of life research. Psycho-Oncology, 8(5), 439-450.

Muncy, J. A., Vitell, S. J. 1992. Consumer ethics: an investigation of the ethical beliefs of the final consumer. Journal of Business Research, 24(4), 297-311.

Osborne, J., Waters, E. (2002). Four assumptions of multiple regression that researchers should always test. Practical Assessment, Research \& Evaluation, 8(2). Retrieved from: http://PAREonline.net/getvn.asp? $\mathrm{v}=8 \& \mathrm{n}=2$

Patwardhan, A. M., Keith, M. E., Vitell, S. J. 2012. Religiosity, attitude toward business, and ethical beliefs: Hispanic consumers in the United States. Journal of business ethics, 110(1), 61-70.

Parboteeah, K. P., Hoegl, M., Cullen, J. B. 2008. Ethics and religion: An empirical test of a multidimensional model. Journal of business ethics, 80(2), 387-398.

Paul, G. 2009. The Chronic Dependence of Popular Religiosity upon Dysfunctional Psychosociological Conditions. Source: http://www.epjournal.net/wp-content/uploads/EP07398441_c.pdf (accessed: 10 February 2014).

Population Reference Bureau. 2011. World Population Data Sheet. Source: http://www.prb.org/pdf11/2011population-data-sheet_eng.pdf. (Accessed: 6 March 2016).

Quah, C. H., Stewart, N., Lee, J. W. C. 2012. Attitudes of business students' toward plagiarism. Journal of Academic Ethics, 10(3), 185-199.

Ramsey, P. 1956. No Morality without Immortality: Dostoevski and the Meaning of Atheism. The Journal of Religion, 90-108.

Rawwas, M. Y. 1996. Consumer ethics: An empirical investigation of the ethical beliefs of Austrian consumers. Journal of Business Ethics, 15(9), 1009-1019.

Rawwas, M. Y. A., Strutton, D., Johnson, L. W. 1996. An exploratory investigation of the ethical values of American and Australian consumers", Journal of Direct Marketing, $10,52-63$.

Rawwas, M. Y. 2001. Culture, personality and morality: A typology of international consumers' ethical beliefs. International Marketing Review, 18(2), 188-211.

Rawwas, M. Y., Patzer, G. L., Klassen, M. L. 1995. Consumer ethics in cross-cultural settings: entrepreneurial implications. European Journal of Marketing, 29(7), 62-78.

Rawwas, M. Y., Swaidan, Z., Oyman, M. 2005. Consumer ethics: A cross-cultural study of the ethical beliefs of Turkish and American consumers. Journal of Business Ethics, 57(2), 183-195.

Rawwas, M. Y., Swaidan, Z., Al-Khatib, J. 2006. Does religion matter? A comparison study of the ethical beliefs of marketing students of religious and secular universities in Japan. Journal of Business Ethics, 65(1), 69-86.

Rawwas, M.Y., Vitell, S.J., Al-Khatib, J.A. 1994. Consumer ethics: the possible effects of terrorism and civil unrest on the ethical values of consumers. Journal of Business Ethics, 13, 223-231. 
Rindfleisch, A., Wong, N., Burroughs, J. E. 2010. God \& Mammon: The influence of religiosity on brand connections. In S. H. K. Wuyts, M. G. Dekimpe, E. Gijsbrecths \& R. Pieters (Eds.), The connected customer: The changing nature of consumer and business markets. Mahwah, NJ: Lawrence-Erlbaum.

Sastriastanti, F.E. 2011. Indonesian lagging behind world in recycling trash. Available at http://www.thejakartaglobe.com/archive/indonesia-lagging-behind-world-inrecycling-trash/ (accessed on 4 March 2013).

Singhapakdi, A., Rawwas, M. Y., Marta, J. K., Ahmed, M. I. 1999. A cross-cultural study of consumer perceptions about marketing ethics. Journal of Consumer Marketing, 16(3), 257-272.

Singhapakdi, A., Vitell, S. J., Lee, D. J., Nisius, A. M., Grace, B. Y. 2013. The influence of love of money and religiosity on ethical decision-making in marketing. Journal of business ethics, 114(1), 183-191.

Silva, F., Ramello, G. B. 2000. Sound recording market: the ambiguous case of copyright and piracy, Industrial and Corporate Change, 9, 415-42.

Spiekermann, S. 2015. Ethical IT Innovation - A Value-based System Design Approach. New York: Taylor \& Francis.

Swaidan, Z. 2012. Culture and consumer ethics. Journal of Business Ethics, 108, 201-213.

Swaidan, Z., Vitell, S. J., Rawwas, M. Y. 2003. Consumer ethics: determinants of ethical beliefs of African Americans. Journal of Business Ethics, 46(2), 175-186.

Tabachnick, B. G., Fidell, L. S. (2001). Using Multivariate Statistics (4th ed.). Needham Heights, MA: Allyn and Bacon.

The Jakarta Post. 2013. Piracy may cost record firms \$1.65m a day. Jakarta Post, April 27, 14.

The World Factbook. 2013. Australia. Source: https://www.cia.gov/library/publications/theworld-factbook/geos/as.html (Accessed: 10 January 2016).

Tittle, C. R., Welch, M. R. 1983. Religiosity and deviance: Toward a contingency theory of constraining effects. Social Forces, 61(3), 653-682.

Topol, M. T., Sherman, E. 1994. Trends and challenges of expanding internationally via direct marketing. Journal of Direct Marketing, 8(1), 32-43.

Vitell, S. J. 2003. Consumer ethics research: Review, synthesis and suggestions for the future. Journal of Business Ethics, 43(1-2), 33-47.

Vitell, S. J. 2009. The role of religiosity in business and consumer ethics: A review of the literature. Journal of Business Ethics, 90(2), 155-167.

Vitell, S. J., Bing, M. N., Davison, H. K., Ammeter, A. P., Garner, B. L., Novicevic, M. M. 2009. Religiosity and moral identity: The mediating role of self-control. Journal of Business Ethics, 88(4), 601-613.

Vitell, S. J., Lumpkin, J. R., Rawwas, M. Y. 1991. Consumer ethics: an investigation of the ethical beliefs of elderly consumers. Journal of Business Ethics, 10(5), 365-375.

Vitell, S. J., Muncy, J. 2005. The Muncy-Vitell consumer ethics scale: A modification and application. Journal of Business Ethics, 62(3), 267-275.

Vitell, S. J., Paolillo, J. G. 2003. Consumer ethics: The role of religiosity. Journal of Business Ethics, 46(2), 151-162.

Vitell, S. J., Paolillo, J. G., Singh, J. J. 2005. Religiosity and consumer ethics. Journal of Business Ethics, 57(2), 175-181.

Vitell, S. J., Singh, J. J., Paolillo, J. G. 2007. Consumers' ethical beliefs: The roles of money, religiosity and attitude toward business. Journal of Business Ethics, 73(4), 369-379.

Vitell, S. J., Singhapakdi, A., Thomas, J. 2001. Consumer ethics: an application and empirical testing of the Hunt-Vitell theory of ethics. Journal of Consumer marketing, 18(2), 153-178. 
Watts, V. J. 2009. Christianity's potential contribution to Australian society. International Journal of New Perspectives in Christianity, 1(1), 1-12.

Wang, F., Zhang, H., Zang, H., Ouyang, M. 2005. Purchasing pirated software: An initial examination of Chinese consumers. Journal of Consumer Marketing, 22(6), 340-351.

Weaver, G. R., Agle, B. R. 2002. Religiosity and ethical behavior in organizations: A symbolic interactionist perspective. Academy of Management Review, 27(1), 77-97.

Wilcox, W. B., Wolfinger, N. H. 2007. Then comes marriage? Religion, race, and marriage in urban America. Social Science Research, 36(2), 569-589.

Wilkes, R. E., Burnett, J. J., Howell, R. D. 1986. On the meaning and measurement of religiosity in consumer research. Journal of the Academy of Marketing Science, 14(1), 47-56.

Woodbine, G. F., Amirthalingam, V. 2013. Dishonesty in the classroom: the effect of cognitive dissonance and the mitigating influence of religious commitment. Journal of Academic Ethics, 11(2), 139-155.

World Bank. 2014. Indonesia. Available at http://data.worldbank.org/country/indonesia (accessed on 29 May 2014). 
Who is more ethical?

\section{APPENDIX}

Figure 1. Conceptual Model

INDEPENDENT VARIABLES

DEPENDENT VARIABLES

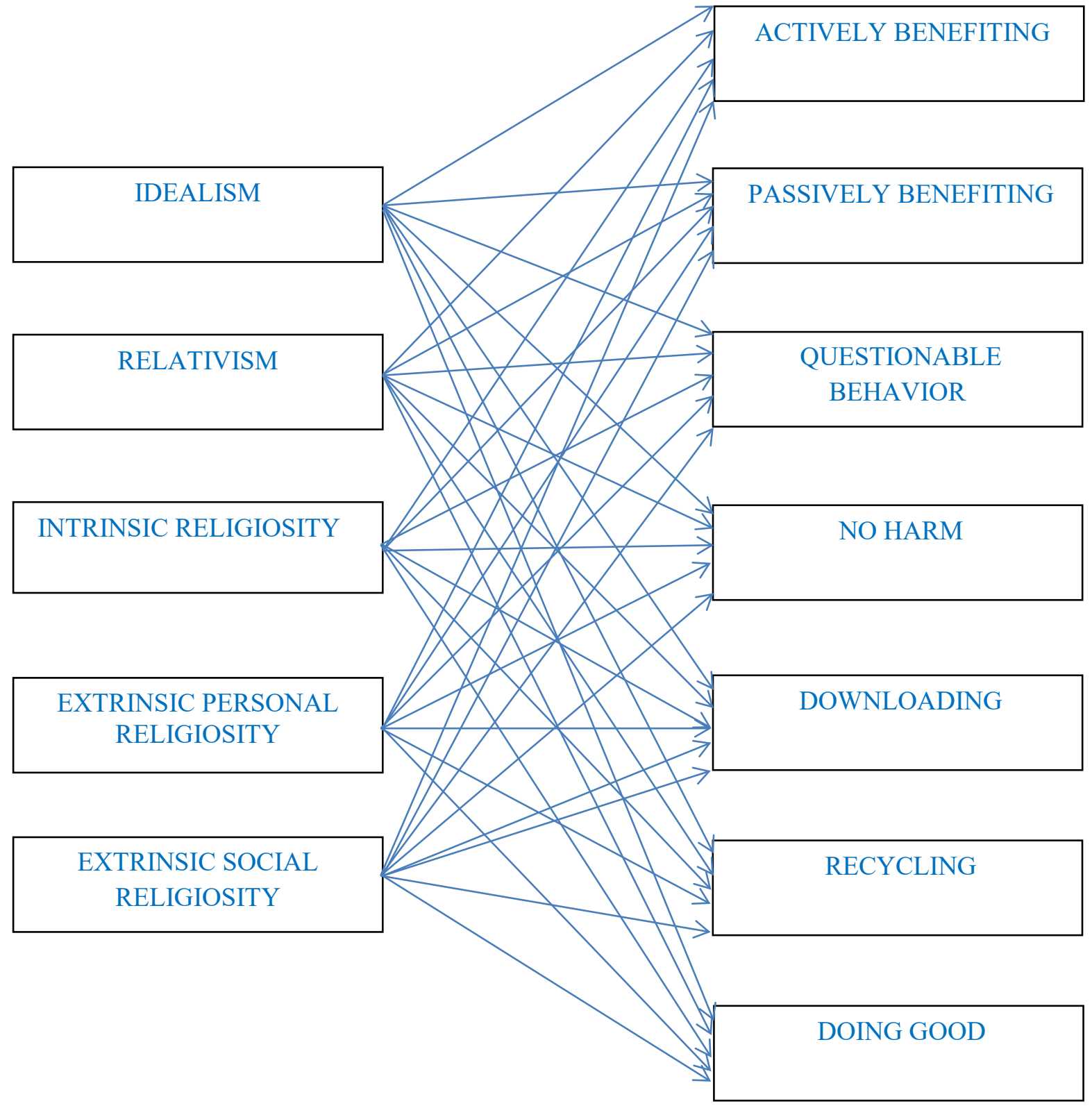


Who is more ethical?

Figure 2. Moral ideology comparison between groups

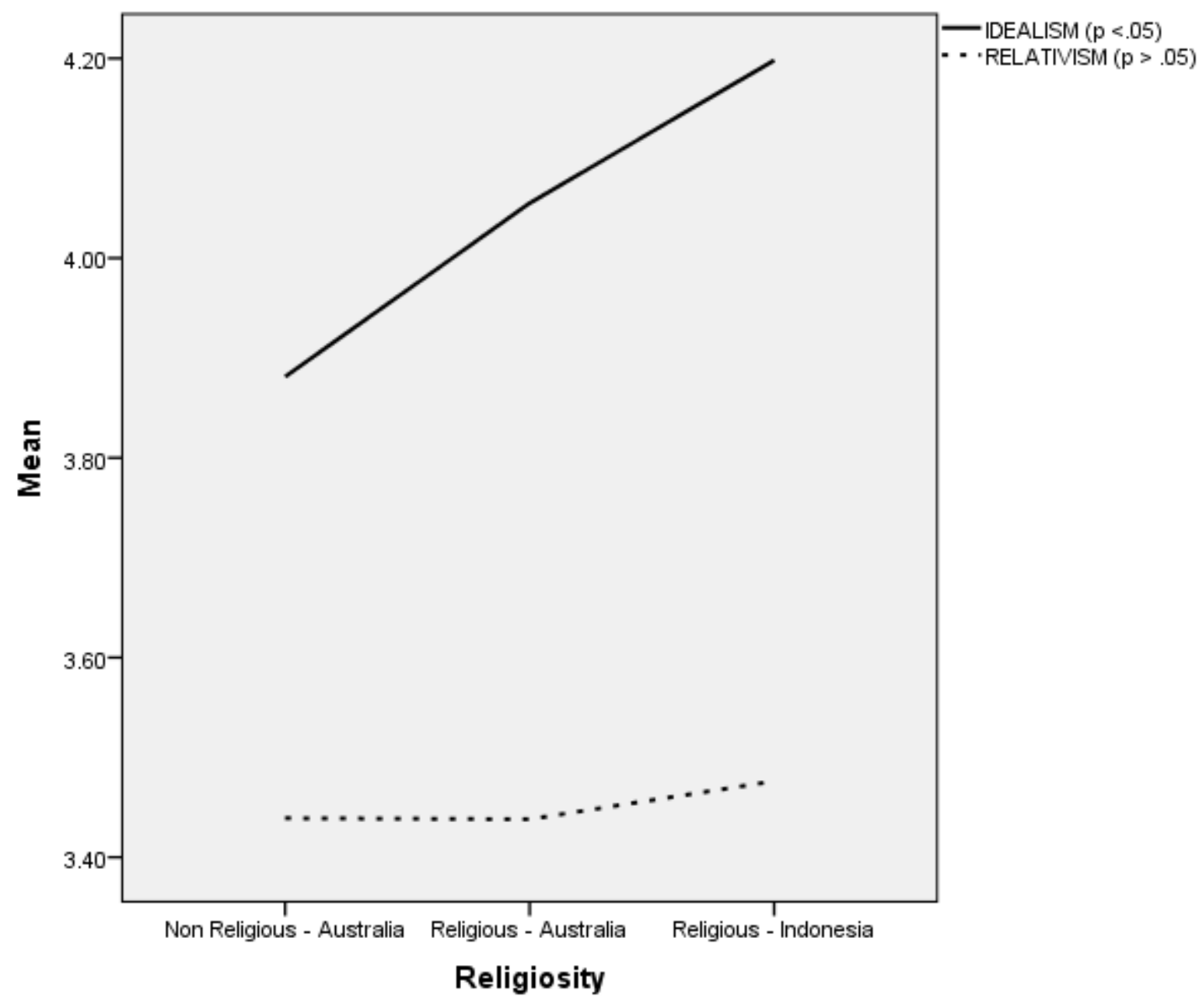

Note: Higher mean values represent higher idealistic and relativistic ideology. 
Figure 3. Ethical beliefs (negative behavior) comparison between groups

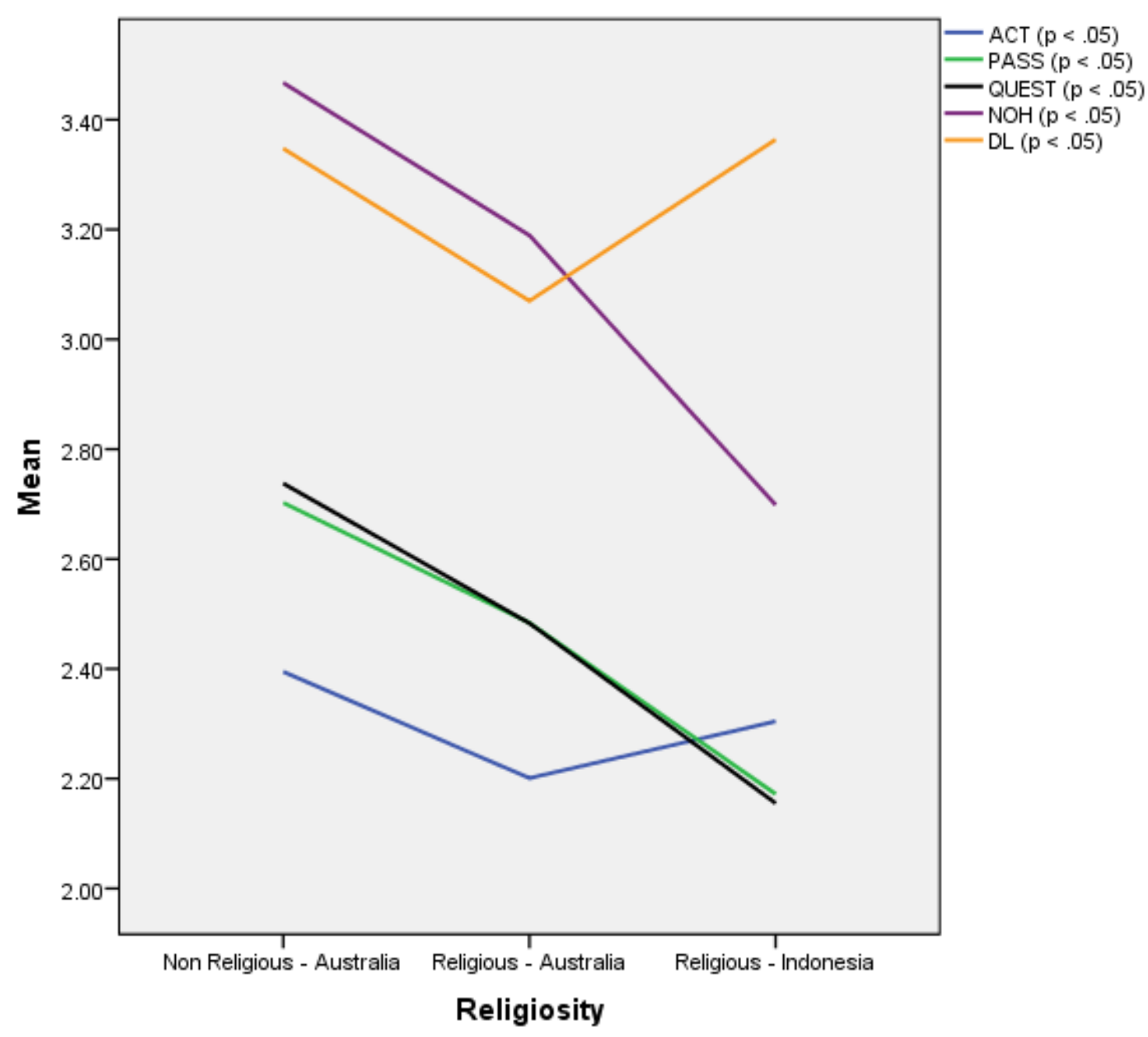

Note: Higher mean values represent higher agreements toward these unethical behaviours; ACT: Actively Benefiting; PASS: Passively Benefiting; QUEST: Questionable Activities; NOH: No-Harm; DL: Downloading; 
Who is more ethical?

Figure 4. Ethical beliefs (positive behavior) between groups

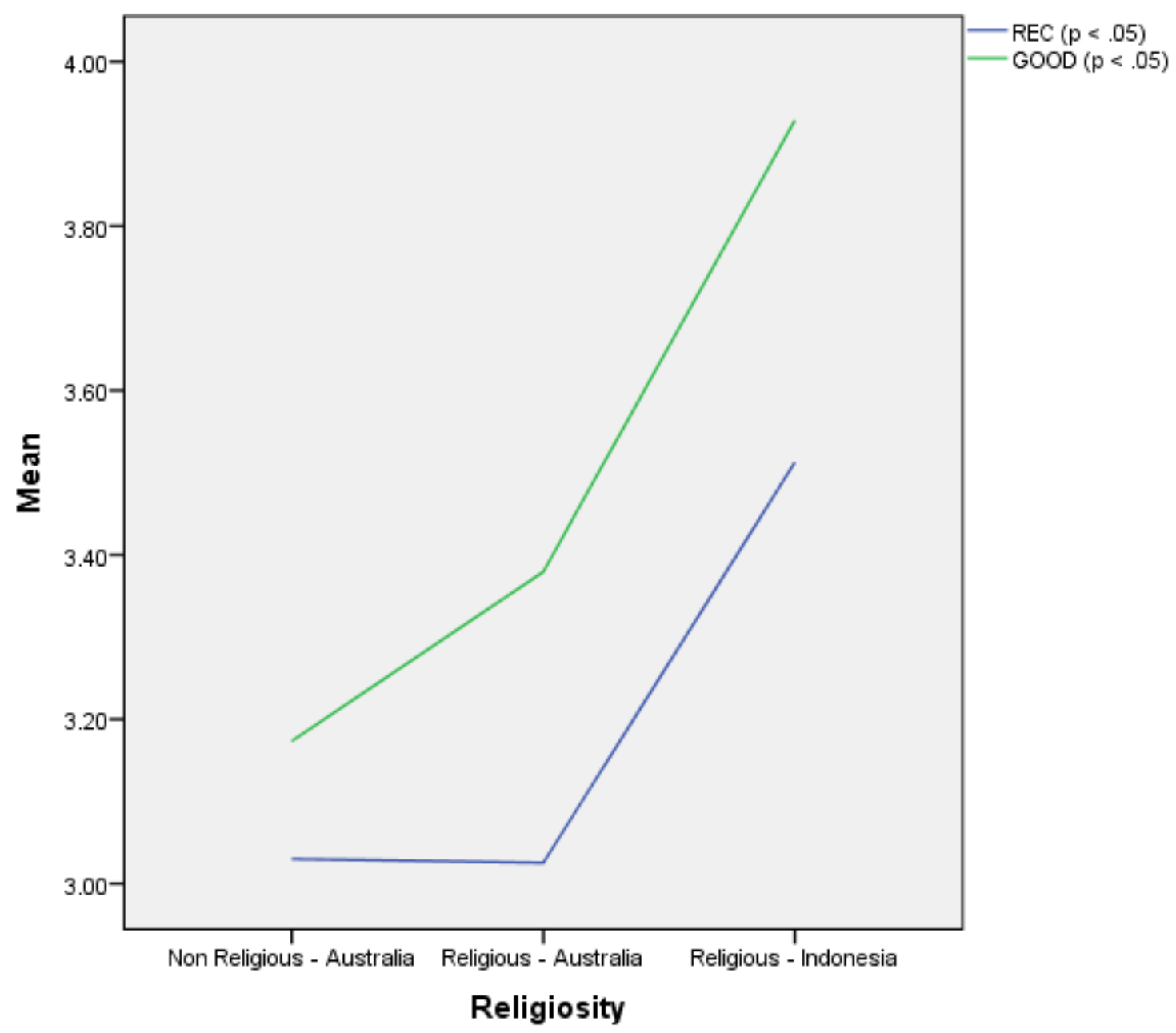

Note: Higher mean values represent higher agreements toward these ethical behavior; REC; Recycling; GOOD: Doing Good. 
Who is more ethical?

Table 1. Demographic Profile.

\begin{tabular}{|l|l|l|l|}
\hline Demographic & & Australia (\%) & Indonesia (\%) \\
\hline Age & $18-24$ years & $58 \%$ & $88 \%$ \\
\hline & $25-35$ years & $22 \%$ & $8 \%$ \\
\hline & $36-44$ years & $8 \%$ & $3 \%$ \\
\hline & $45-54$ years & $12 \%$ & $1 \%$ \\
\hline Gender & & & \\
\hline & Male & $49 \%$ & $34 \%$ \\
\hline & Female & $51 \%$ & $66 \%$ \\
\hline Marital Status & & & \\
\hline & Single & $65 \%$ & $90 \%$ \\
\hline & Married & $22 \%$ & $6 \%$ \\
\hline & Divorced & $2 \%$ & $0 \%$ \\
\hline & Widowed & $1 \%$ & $2 \%$ \\
\hline & Others & $10 \%$ & $2 \%$ \\
\hline Religion & & & \\
\hline & Islam & $3 \%$ & $30 \%$ \\
\hline & Christian/ Catholic & $39 \%$ & $20 \%$ \\
\hline & Buddhism & $7 \%$ & $18 \%$ \\
\hline & Hinduism & $1 \%$ & $28 \%$ \\
\hline & Others & $14 \%$ & $3 \%$ \\
\hline & No religion & $36 \%$ & $1 \%$ \\
\hline
\end{tabular}


Table 2. Independent t-test results between religious and non-religious group.

\begin{tabular}{|c|c|c|c|c|c|c|}
\hline \multirow[t]{2}{*}{ Construct } & \multicolumn{3}{|c|}{ Group } & \multirow[t]{2}{*}{$\mathbf{F}$} & \multirow[t]{2}{*}{ Sig } & \multirow[t]{2}{*}{ Note: at $p<.05$} \\
\hline & $\begin{array}{l}\text { A. Religious } \\
\text { (Indonesia) } \\
(\mathrm{N}=441)\end{array}$ & $\begin{array}{l}\text { B. Religious } \\
\text { (Australia) } \\
(\mathbf{N}=416)\end{array}$ & $\begin{array}{l}\text { C. Non- } \\
\text { Religious } \\
\text { (Australia) } \\
(\mathbf{N}=\mathbf{2 2 3})\end{array}$ & & & \\
\hline Idealism & 4.20 & 4.04 & 3.86 & 19.094 & 0.000 & $\begin{array}{l}\text { - C is sig different than } \mathrm{A}, \mathrm{B} \\
\text { - B is sig different than A }\end{array}$ \\
\hline Relativism & 3.48 & 3.46 & 3.47 & 0.133 & 0.876 & No sig different \\
\hline Actively Benefiting & 2.30 & 2.29 & 2.43 & 2.502 & 0.082 & No sig different \\
\hline Passively Benefiting & 2.17 & 2.56 & 2.73 & 40.652 & 0.000 & - A is sig different than $\mathrm{B}, \mathrm{C}$ \\
\hline Questionable Behavior & 2.16 & 2.54 & 2.76 & 45.296 & 0.000 & $\begin{array}{l}\text { - C is sig different than A,B } \\
\text { - B is sig different than A }\end{array}$ \\
\hline No-Harm & 2.70 & 3.24 & 3.47 & 70.574 & 0.000 & $\begin{array}{l}\text { - } \mathrm{C} \text { is sig different than } \mathrm{A}, \mathrm{B} \\
-\mathrm{B} \text { is sig different than } \mathrm{A}\end{array}$ \\
\hline Downloading & 3.36 & 3.12 & 3.37 & 8.867 & 0.000 & $\begin{array}{l}-\mathrm{C} \text { is sig different than } \mathrm{B} \\
-\mathrm{B} \text { is sig different than } \mathrm{A}\end{array}$ \\
\hline Recycling & 3.51 & 3.02 & 3.03 & 60.017 & 0.000 & - A is sig different than $\mathrm{B}, \mathrm{C}$ \\
\hline Doing-good & 3.93 & 3.35 & 3.15 & 67.375 & 0.000 & $\begin{array}{l}\text { - } \mathrm{C} \text { is sig different than A, B } \\
\text { - B is sig different than A }\end{array}$ \\
\hline
\end{tabular}


Table 3. Correlation matrix for religious consumers - Indonesia.

\begin{tabular}{|c|c|c|c|c|c|c|c|c|c|c|c|c|}
\hline Construct & 1 & 2 & 3 & 4 & 5 & 6 & 7 & 8 & 9 & 10 & 11 & 12 \\
\hline 1. ACT & 1 & & & & & & & & & & & \\
\hline 2. PASS & $0.692 * *$ & 1 & & & & & & & & & & \\
\hline 3. QUEST & $0.558 * *$ & $0.743 * *$ & 1 & & & & & & & & & \\
\hline 4. $\mathrm{NOH}$ & $0.416^{* *}$ & $0.515^{* *}$ & $0.569 * *$ & 1 & & & & & & & & \\
\hline 5. DL & $0.158^{* *}$ & $0.256^{* *}$ & $0.280^{* *}$ & $0.479 * *$ & 1 & & & & & & & \\
\hline 6. REC & 0.047 & 0.008 & 0.025 & $0.162 * *$ & $0.297 * *$ & 1 & & & & & & \\
\hline 7. GOOD & -0.066 & $-0.127 * *$ & $-0.097 *$ & 0.053 & $0.181^{* *}$ & $0.372 * *$ & 1 & & & & & \\
\hline 8. IDE & $-0.139 *$ & $-0.198 * *$ & $-0.224 * *$ & $-0.209 * *$ & -0.080 & 0.077 & $0.160 * *$ & 1 & & & & \\
\hline 9. REL & $0.113^{*}$ & $0.108^{*}$ & $0.136 * *$ & 0.018 & 0.055 & -0.011 & -0.001 & 0.016 & 1 & & & \\
\hline 10. INT & $-0.137 * *$ & $-0.284 * *$ & $-0.306 * *$ & $-0.221 * *$ & -0.015 & 0.180 & 0.162 & $0.168 * *$ & 0.041 & 1 & & \\
\hline 11. EXTP & 0.064 & $-0.109 *$ & $-0.181 * *$ & -0.044 & 0.027 & $0.173 * *$ & $0.198 * *$ & $0.171^{* *}$ & 0.031 & $0.395 * *$ & 1 & \\
\hline 12. EXTS & $0.207 * *$ & $-0.165 * *$ & 0.079 & $0.156^{* *}$ & -0.030 & 0.052 & -0.048 & -0.010 & 0.010 & 0.020 & $0.224 * *$ & 1 \\
\hline
\end{tabular}

Note -2 -tailed significance: $* p<0.01 .{ }^{*} p<0.005$.

ACT: Actively Benefiting; PASS: Passively Benefiting; QUEST: Questionable Activities; NOH: No-Harm; DL: Downloading; REC: Recycling; GOOD: Doing Good; IDE:

Idealism; REL: Relativism; INT: Intrinsic Religious Orientation; EXTP: Extrinsic Personal Religious Orientation; EXTS: Extrinsic Social Religious Orientation. 
Table 4. Correlation matrix for religious consumers - Australia.

\begin{tabular}{|c|c|c|c|c|c|c|c|c|c|c|c|c|}
\hline Construct & 1 & 2 & 3 & 4 & 5 & 6 & 7 & 8 & 9 & 10 & 11 & 12 \\
\hline 1. ACT & 1 & & & & & & & & & & & \\
\hline 2. PASS & $0.711 * *$ & 1 & & & & & & & & & & \\
\hline 3. QUEST & $0.605 * *$ & $0.805 * *$ & 1 & & & & & & & & & \\
\hline 4. $\mathrm{NOH}$ & $0.349 * *$ & $0.546^{* *}$ & $0.524 * *$ & 1 & & & & & & & & \\
\hline 5. DL & $0.312 * *$ & $0.448 * *$ & $0.430 * *$ & $0.631 * *$ & 1 & & & & & & & \\
\hline 6. REC & 0.050 & 0.066 & 0.093 & 0.030 & 0.097 & 1 & & & & & & \\
\hline 7. GOOD & $-0.203^{*}$ & $-0.357 * *$ & $-0.296^{*}$ & $0.239 * *$ & $0.138 * *$ & $0.171 * *$ & 1 & & & & & \\
\hline 8. IDE & $-0.197 * *$ & $-0.187^{*}$ & $-0.225 * *$ & -0.095 & -0.101 & -0.063 & 0.099 & 1 & & & & \\
\hline 9. REL & -0.099 & 0.014 & 0.035 & 0.031 & 0.072 & 0.076 & $-0.103^{*}$ & 0.061 & 1 & & & \\
\hline 10. INT & -0.096 & $-0.220 * *$ & $-0.208 * *$ & $-0.200 * *$ & $-0.146 * *$ & 0.094 & $0.201 * *$ & $0.143 * *$ & 0.014 & 1 & & \\
\hline 11. ЕXTP & -0.012 & $-0.144 * *$ & -0.188 & -0.095 & -0.068 & 0.100 & $0.114^{*}$ & $0.143^{* *}$ & $0.110^{*}$ & $0.607 * *$ & 1 & \\
\hline 12. EXTS & 0.008 & -0.014 & 0.007 & $-0.115^{*}$ & -0.082 & $0.112^{*}$ & 0.044 & -0.039 & -0.024 & $0.485 * *$ & $0.425 * *$ & 1 \\
\hline
\end{tabular}

Note -2 -tailed significance: $* p<0.01$. $* * p<0.005$.

ACT: Actively Benefiting; PASS: Passively Benefiting; QUEST: Questionable Activities; NOH: No-Harm; DL: Downloading; REC; Recycling; GOOD: Doing Good; IDE:

Idealism; REL: Relativism; INT: Intrinsic Religious Orientation; EXTP: Extrinsic Personal Religious Orientation; EXTS: Extrinsic Social Religious Orientation. 
Table 5. Correlation matrix for non-religious consumers - Australia.

\begin{tabular}{|l|l|l|l|l|l|l|l|l|l|}
\hline Construct & $\mathbf{1}$ & $\mathbf{2}$ & $\mathbf{3}$ & $\mathbf{4}$ & $\mathbf{5}$ & $\mathbf{6}$ & $\mathbf{7}$ & $\mathbf{8}$ & $\mathbf{9}$ \\
\hline 1. ACT & 1 & & & & & & & \\
\hline 2. PASS & $0.671^{* *}$ & 1 & & & & & & \\
\hline 3. QUEST & $0.672^{* *}$ & $0.795^{* *}$ & 1 & & & & & \\
\hline 4. NOH & $0.448^{* *}$ & $0.672^{* *}$ & $0.620^{* *}$ & 1 & & & & \\
\hline 5. DL & $0.470^{* *}$ & $0.598^{* *}$ & $0.527^{* *}$ & $0.731^{* *}$ & 1 & & & \\
\hline 6. REC & -0.092 & 0.003 & 0.024 & -0.049 & -0.051 & 1 & & \\
\hline 7. GOOD & $-0.253^{* *}$ & $-0.395^{* *}$ & $-0.372^{* *}$ & $-0.378^{* *}$ & $-0.407^{* *}$ & $0.176^{* *}$ & 1 & \\
\hline 8. IDE & $-0.141^{*}$ & -0.075 & -0.083 & -0.041 & -0.004 & 0.013 & 0.031 & \\
\hline 9. REL & 0.030 & 0.038 & 0.041 & 0.056 & 0.014 & -0.116 & -0.101 & \\
\hline
\end{tabular}

Note -2 -tailed significance: $* p<0.01$. $* * p<0.005$.

ACT: Actively Benefiting; PASS: Passively Benefiting; QUEST: Questionable Activities; NOH: No-Harm; DL: Downloading; REC; Recycling; GOOD: Doing Good; IDE: Idealism; REL: Relativism; INT: Intrinsic Religious Orientation; EXTP: Extrinsic Personal Religious Orientation; EXTS: Extrinsic Social Religious Orientation. 
Who is more ethical?

Table 6. Regression analyses for religious consumers - Indonesia.

\begin{tabular}{|c|c|c|c|c|}
\hline \multicolumn{2}{|c|}{ Model } & Standardized beta & \multirow[t]{2}{*}{ t-value } & \multirow[t]{2}{*}{ Sig } \\
\hline \multirow[t]{9}{*}{ (a) } & \multicolumn{2}{|c|}{ Dependent variable: actively benefiting } & & \\
\hline & Constant & & 6.418 & 0.000 \\
\hline & Idealism & -0.129 & -2.777 & 0.006 \\
\hline & Relativism & 0.116 & 2.554 & 0.011 \\
\hline & Intrinsic Religiosity & -0.166 & -3.325 & 0.001 \\
\hline & Extrinsic Personal Religiosity & 0.107 & 2.077 & $\mathbf{0 . 0 3 8}$ \\
\hline & Extrinsic Social Religiosity & 0.184 & 3.933 & $\mathbf{0 . 0 0 0}$ \\
\hline & $\mathrm{R}^{2}=0.099$ & F-value $=9.549$ & & \\
\hline & Adjusted $\mathrm{R}^{2}=0.089$ & Significance $=\mathbf{0 . 0 0 0}$ & & \\
\hline \multirow{9}{*}{ (b) } & \multicolumn{2}{|c|}{ Dependent variable: passively benefiting } & & \\
\hline & Constant & & 8.979 & 0.000 \\
\hline & Idealism & -0.151 & -3.336 & $\mathbf{0 . 0 0 1}$ \\
\hline & Relativism & 0.120 & 2.703 & $\mathbf{0 . 0 0 7}$ \\
\hline & Intrinsic Religiosity & -0.258 & -5.308 & $\mathbf{0 . 0 0 0}$ \\
\hline & Extrinsic Personal Religiosity & -0.023 & -0.467 & 0.641 \\
\hline & Extrinsic Social Religiosity & 0.173 & 3.783 & $\mathbf{0 . 0 0 0}$ \\
\hline & $\mathrm{R}^{2}=0.147$ & F-value $=15.014$ & & \\
\hline & Adjusted $\mathrm{R}^{2}=0.137$ & Significance $=\mathbf{0 . 0 0 0}$ & & \\
\hline \multirow[t]{9}{*}{ (c) } & \multicolumn{2}{|c|}{ Dependent variable: questionable behavior } & & \\
\hline & Constant & & 9.602 & 0.000 \\
\hline & Idealism & -0.170 & -3.777 & $\mathbf{0 . 0 0 0}$ \\
\hline & Relativism & 0.150 & 3.415 & 0.001 \\
\hline & Intrinsic Religiosity & -0.255 & -5.277 & $\mathbf{0 . 0 0 0}$ \\
\hline & Extrinsic Personal Religiosity & -0.078 & -1.574 & 0.116 \\
\hline & Extrinsic Social Religiosity & 0.099 & 2.178 & $\mathbf{0 . 0 3 0}$ \\
\hline & $\mathrm{R}^{2}=0.159$ & F-value $=16.388$ & & \\
\hline & Adjusted $\mathrm{R}^{2}=0.1549$ & Significance $=\mathbf{0 . 0 0 0}$ & & \\
\hline \multirow[t]{9}{*}{ (d) } & \multicolumn{2}{|l|}{ Dependent variable: no-harm } & & \\
\hline & Constant & & 9.902 & 0.000 \\
\hline & Idealism & -0.179 & -3.860 & $\mathbf{0 . 0 0 0}$ \\
\hline & Relativism & 0.027 & 0.600 & 0.549 \\
\hline & Intrinsic Religiosity & -0.209 & -4.197 & 0.000 \\
\hline & Extrinsic Personal Religiosity & 0.035 & 0.678 & 0.498 \\
\hline & Extrinsic Social Religiosity & 0.150 & 3.212 & 0.001 \\
\hline & $\mathrm{R}^{2}=0.106$ & F-value $=10.306$ & & \\
\hline & Adjusted $\mathrm{R}^{2}=0.096$ & Significance $=\mathbf{0 . 0 0 0}$ & & \\
\hline \multirow[t]{9}{*}{ (e) } & \multicolumn{2}{|c|}{ Dependent variable: downloading } & & \\
\hline & Constant & & 7.510 & 0.000 \\
\hline & Idealism & -0.087 & -1.795 & 0.073 \\
\hline & Relativism & 0.056 & 1.168 & 0.244 \\
\hline & Intrinsic Religiosity & -0.025 & -0.479 & 0.632 \\
\hline & Extrinsic Personal Religiosity & 0.060 & 1.111 & 0.267 \\
\hline & Extrinsic Social Religiosity & -0.044 & -0.904 & 0.366 \\
\hline & $\mathrm{R}^{2}=0.013$ & F-value $=1.176$ & & \\
\hline & Adjusted $\mathrm{R}^{2}=0.002$ & Significance $=0.320$ & & \\
\hline
\end{tabular}


Who is more ethical?

Table 6 (Cont.). Regression analyses for religious consumers - Indonesia.

\begin{tabular}{|c|c|c|c|c|}
\hline \multicolumn{2}{|c|}{ Model } & Standardized beta & \multirow[t]{2}{*}{ t-value } & \multirow[t]{2}{*}{ Sig } \\
\hline (f) & Dependent variable: recycling & & & \\
\hline & Constant & & 6.092 & 0.000 \\
\hline & Idealism & 0.037 & 0.783 & 0.434 \\
\hline & Relativism & -0.021 & -0.441 & 0.659 \\
\hline & Intrinsic Religiosity & 0.130 & 2.536 & $\mathbf{0 . 0 1 2}$ \\
\hline & Extrinsic Personal Religiosity & 0.110 & 2.078 & 0.038 \\
\hline & Extrinsic Social Religiosity & 0.026 & 0.537 & 0.592 \\
\hline & $\mathrm{R}^{2}=0.047$ & F-value $=4.28$ & & \\
\hline & Adjusted $\mathrm{R}^{2}=0.036$ & Significance $=\mathbf{0 . 0 0 1}$ & & \\
\hline (g) & Dependent variable: doing-goo & & & \\
\hline & Constant & & 3.608 & 0.000 \\
\hline & Idealism & 0.118 & 2.486 & 0.013 \\
\hline & Relativism & -0.010 & -0.216 & 0.829 \\
\hline & Intrinsic Religiosity & 0.079 & 1.556 & 0.121 \\
\hline & Extrinsic Personal Religiosity & 0.166 & 3.180 & $\mathbf{0 . 0 0 2}$ \\
\hline & Extrinsic Social Religiosity & -0.086 & -1.796 & 0.073 \\
\hline & $\mathrm{R}^{2}=0.069$ & F-value $=6.407$ & & \\
\hline & Adjusted $\mathrm{R}^{2}=0.058$ & Significance $=\mathbf{0 . 0 0 0}$ & & \\
\hline
\end{tabular}


Who is more ethical?

Table 7. Regression analyses for religious consumers - Australia.

\begin{tabular}{|c|c|c|c|c|}
\hline \multicolumn{2}{|c|}{ Model } & Standardized beta & \multirow[t]{2}{*}{ t-value } & \multirow[t]{2}{*}{ Sig } \\
\hline \multirow[t]{9}{*}{ (a) } & \multicolumn{2}{|c|}{ Dependent variable: actively benefiting } & & \\
\hline & Constant & & 9.359 & 0.000 \\
\hline & Idealism & -0.173 & -3.314 & 0.001 \\
\hline & Relativism & 0.023 & -0.455 & 0.649 \\
\hline & Intrinsic Religiosity & -0.183 & -2.689 & 0.007 \\
\hline & Extrinsic Personal Religiosity & 0.061 & 0.918 & 0.359 \\
\hline & Extrinsic Social Religiosity & 0.155 & 2.588 & $\mathbf{0 . 0 1 0}$ \\
\hline & $\mathrm{R}^{2}=0.067$ & F-value $=5.186$ & & \\
\hline & Adjusted $\mathrm{R}^{2}=0.054$ & Significance $=\mathbf{0 . 0 0 0}$ & & \\
\hline \multirow[t]{9}{*}{ (b) } & \multicolumn{2}{|c|}{ Dependent variable: passively benefiting } & & \\
\hline & Constant & & 10.144 & 0.000 \\
\hline & Idealism & -0.147 & -2.855 & 0.005 \\
\hline & Relativism & 0.032 & 0.625 & 0.533 \\
\hline & Intrinsic Religiosity & -0.233 & -3.460 & 0.001 \\
\hline & Extrinsic Personal Religiosity & 0.030 & -0.455 & 0.649 \\
\hline & Extrinsic Social Religiosity & 0.106 & 1.791 & 0.074 \\
\hline & $\mathrm{R}^{2}=0.082$ & F-value $=6.464$ & & \\
\hline & Adjusted $\mathrm{R}^{2}=0.069$ & Significance $=\mathbf{0 . 0 0 0}$ & & \\
\hline \multirow[t]{9}{*}{ (c) } & \multicolumn{2}{|c|}{ Dependent variable: questionable behavior } & & \\
\hline & Constant & & 10.432 & 0.000 \\
\hline & Idealism & -0.193 & -3.763 & 0.000 \\
\hline & Relativism & 0.048 & 0.939 & 0.021 \\
\hline & Intrinsic Religiosity & -0.263 & -3.930 & $\mathbf{0 . 0 0 0}$ \\
\hline & Extrinsic Personal Religiosity & 0.048 & 0.735 & 0.514 \\
\hline & Extrinsic Social Religiosity & 0.108 & 1.836 & 0.002 \\
\hline & $\mathrm{R}^{2}=0.096$ & F-value $=7.694$ & & \\
\hline & Adjusted $\mathrm{R}^{2}=0.084$ & Significance $=\mathbf{0 . 0 0 0}$ & & \\
\hline \multirow[t]{9}{*}{ (d) } & \multicolumn{2}{|l|}{ Dependent variable: no-harm } & & \\
\hline & Constant & & 10.828 & 0.000 \\
\hline & Idealism & -0.077 & -1.469 & 0.143 \\
\hline & Relativism & 0.032 & 0.612 & 0.541 \\
\hline & Intrinsic Religiosity & -0.201 & -2.922 & 0.004 \\
\hline & Extrinsic Personal Religiosity & 0.052 & 0.778 & 0.437 \\
\hline & Extrinsic Social Religiosity & -0.042 & -0.694 & 0.488 \\
\hline & $\mathrm{R}^{2}=0.139$ & F-value $=27.733$ & & \\
\hline & Adjusted $\mathrm{R}^{2}=0.134$ & Significance $=\mathbf{0 . 0 0 3}$ & & \\
\hline \multirow[t]{9}{*}{ (e) } & \multicolumn{2}{|c|}{ Dependent variable: downloading } & & \\
\hline & Constant & & 12.348 & 0.000 \\
\hline & Idealism & -0.092 & -2.840 & 0.084 \\
\hline & Relativism & 0.075 & 2.527 & 0.152 \\
\hline & Intrinsic Religiosity & -0.140 & 0.603 & $\mathbf{0 . 0 4 3}$ \\
\hline & Extrinsic Personal Religiosity & 0.035 & 0.568 & 0.599 \\
\hline & Extrinsic Social Religiosity & -0.030 & -1.741 & 0.620 \\
\hline & $\mathrm{R}^{2}=0.035$ & F-value $=2.631$ & & \\
\hline & Adjusted $\mathrm{R}^{2}=0.022$ & Significance $=\mathbf{0 . 0 2 1}$ & & \\
\hline
\end{tabular}


Who is more ethical?

Table 7 (Cont.). Regression analyses for religious consumers - Australia.

\begin{tabular}{|l|l|l|r|l|}
\hline \multicolumn{2}{|l|}{ Model } & Standardized beta & t-value & Sig \\
\hline (f) & Dependent variable: recycling & & & \\
\hline & Constant & -0.078 & 9.518 & 0.000 \\
\hline & Idealism & 0.077 & -1.458 & 0.146 \\
\hline & Relativism & 0.040 & 1.461 & 0.145 \\
\hline & Intrinsic Religiosity & 0.049 & 0.573 & 0.567 \\
\hline & Extrinsic Personal Religiosity & 0.071 & 0.723 & 0.470 \\
\hline & Extrinsic Social Religiosity & F-value $=18.932$ & & 0.071 \\
\hline & $\mathrm{R}^{2}=0.027$ & Significance $=0.074$ & & \\
\hline & Adjusted R ${ }^{2}=0.014$ & & & \\
\hline & \multicolumn{2}{|l|}{} & & \\
\hline (g) & Dependent variable: doing-good & & 9.614 & 0.000 \\
\hline & Constant & 0.062 & 1.868 & 0.178 \\
\hline & Idealism & -0.058 & -1.806 & $\mathbf{0 . 0 2 9}$ \\
\hline & Relativism & 0.257 & 6.046 & $\mathbf{0 . 0 0 2}$ \\
\hline & Intrinsic Religiosity & 0.095 & -2.189 & 0.836 \\
\hline & Extrinsic Personal Religiosity & -0.087 & -2.486 & 0.269 \\
\hline & Extrinsic Social Religiosity & F-value $=4.661$ & & \\
\hline & $\mathrm{R}^{2}=0.061$ & Significance $=\mathbf{0 . 0 0 0}$ & & \\
\hline & Adjusted R ${ }^{2}=0.048$ & & \\
\hline
\end{tabular}


Who is more ethical?

Table 8. Regression analyses for non-religious consumers - Australia.

\begin{tabular}{|c|c|c|c|c|}
\hline \multicolumn{2}{|c|}{ Model } & Standardized beta & \multirow[t]{2}{*}{ t-value } & \multirow[t]{2}{*}{ Sig } \\
\hline (a) & \begin{tabular}{|l} 
Dependent variable: \\
\end{tabular} & & & \\
\hline & Constant & & 7.132 & 0.000 \\
\hline & Idealism & -0.150 & -1.183 & $\mathbf{0 . 0 3 3}$ \\
\hline & Relativism & 0.056 & 0.798 & 0.426 \\
\hline & $\mathrm{R}^{2}=0.023$ & F-value $=2.409$ & & \\
\hline & Adjusted $\mathrm{R}^{2}=0.013$ & Significance $=0.092$ & & \\
\hline \multirow{6}{*}{ (b) } & \multicolumn{2}{|c|}{ Dependent variable: passively benefiting } & & \\
\hline & Constant & & 6.454 & 0.000 \\
\hline & Idealism & -0.083 & -1.183 & 0.238 \\
\hline & Relativism & 0.052 & 0.737 & 0.462 \\
\hline & $\mathrm{R}^{2}=0.008$ & F-value $=0.848$ & & \\
\hline & Adjusted $\mathrm{R}^{2}=0.001$ & Significance $=0.430$ & & \\
\hline \multirow[t]{6}{*}{ (c) } & \multicolumn{2}{|c|}{ Dependent variable: questionable behavior } & & \\
\hline & Constant & & 6.490 & 0.000 \\
\hline & Idealism & -0.093 & -1.318 & 0.189 \\
\hline & Relativism & 0.056 & 0.800 & 0.425 \\
\hline & $\mathrm{R}^{2}=0.010$ & F-value $=1.718$ & & \\
\hline & Adjusted $\mathrm{R}^{2}=0.000$ & Significance $=0.182$ & & \\
\hline \multirow{6}{*}{ (d) } & \multicolumn{2}{|c|}{ Dependent variable: no-harm } & & \\
\hline & Constant & & 7.055 & 0.000 \\
\hline & Idealism & -0.052 & -0.738 & 0.461 \\
\hline & Relativism & 0.065 & 0.922 & 0.358 \\
\hline & $\mathrm{R}^{2}=0.006$ & F-value $=0.599$ & & \\
\hline & Adjusted $\mathrm{R}^{2}=0.004$ & Significance $=0.550$ & & \\
\hline \multirow[t]{6}{*}{ (e) } & \multicolumn{2}{|c|}{ Dependent variable: downloading } & & \\
\hline & Constant & & 7.135 & 0.000 \\
\hline & Idealism & -0.007 & -0.095 & 0.740 \\
\hline & Relativism & 0.015 & 0.219 & 0.998 \\
\hline & $\mathrm{R}^{2}=0.000$ & F-value $=0.026$ & & \\
\hline & Adjusted $\mathrm{R}^{2}=0.009$ & Significance $=0.975$ & & \\
\hline \multirow[t]{6}{*}{ (f) } & \multicolumn{2}{|c|}{ Dependent variable: recycling } & & \\
\hline & Constant & & 8.512 & 0.000 \\
\hline & Idealism & 0.033 & 0.475 & 0.636 \\
\hline & Relativism & -0.122 & -1.738 & 0.084 \\
\hline & $\mathrm{R}^{2}=0.015$ & F-value $=1.597$ & & \\
\hline & Adjusted $\mathrm{R}^{2}=0.005$ & Significance $=0.205$ & & \\
\hline \multirow{6}{*}{ (g) } & \multicolumn{2}{|c|}{ Dependent variable: doing-good } & & \\
\hline & Constant & & 7.984 & 0.000 \\
\hline & Idealism & 0.049 & 0.969 & 0.482 \\
\hline & Relativism & -0.109 & -1.460 & 0.122 \\
\hline & $\mathrm{R}^{2}=0.013$ & F-value $=1.307$ & & \\
\hline & Adjusted $\mathrm{R}^{2}=0.003$ & Significance $=0.273$ & & \\
\hline
\end{tabular}

